듬 SCHOOL of GRADUATE STUDIES

EAST TENNESSEE STATE UNIVERSITY
East Tennessee State University Digital Commons@ East Tennessee State University

May 1996

\title{
The Relationships Among Leadership Behaviors of Leaders in Training Organizations, Training Methods, and Organization Profitability
}

Joseph D. Keith

East Tennessee State University

Follow this and additional works at: https://dc.etsu.edu/etd

Part of the Business Administration, Management, and Operations Commons, and the Educational Administration and Supervision Commons

\section{Recommended Citation}

Keith, Joseph D., "The Relationships Among Leadership Behaviors of Leaders in Training Organizations, Training Methods, and Organization Profitability" (1996). Electronic Theses and Dissertations. Paper 2930. https://dc.etsu.edu/etd/2930

This Dissertation - Open Access is brought to you for free and open access by the Student Works at Digital Commons @ East Tennessee State University. It has been accepted for inclusion in Electronic Theses and Dissertations by an authorized administrator of Digital Commons @ East

Tennessee State University. For more information, please contact digilib@etsu.edu. 


\section{INFORMATION TO USERS}

This manuscript has been reproduced from the microfilm master. UMI films the text directly from the original or copy submitted. Thus, some thesis and dissertation copies are in typewriter face, while others may be from any type of computer printer.

The quality of this reproduction is dependent upon the quality of the copy submitted. Broken or indistinct print, colored or poor quality illustrations and photographs, print bleedthrough, substandard margins, and improper alignment can adversely affect reproduction.

In the unlikely event that the author did not send UMI a complete manuscript and there are missing pages, these will be noted. Also, if unauthorized copyright material had to be removed, a note will indicate the deletion.

Oversize materials (e.g., maps, drawings, charts) are reproduced by sectioning the original, beginning at the upper left-hand comer and continuing from left to right in equal sections with small overlaps. Each original is also photographed in one exposure and is included in reduced form at the back of the book.

Photographs included in the original manuscript have been reproduced xerographically in this copy. Higher quality $6 " \times 9 "$ black and white photographic prints are available for any photographs or illustrations appearing in this copy for an additional charge. Contact UMI directly to order.

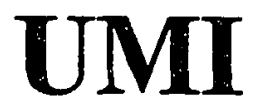

A Bell \& Howell Information Company

300 North Z 20 Prad, Ann Arbor MI 48106-1346 USA

$313 / 761-4700 \quad 800 / 521-0600$ 
Reproduced with permission of the copyright owner. Further reproduction prohibited without permission. 


\title{
THE RELATIONSHIPS AMONG IEADERSHIP BEHAVIORS OF \\ LEADERS IN TRAINING ORGANIZATIONS, TRAINING \\ METHODS, AND ORGANIZATION PROFITABILITY
}

\begin{abstract}
A Dissertation
Presented to

The Faculty of Educational Leadership and Policy Analysis

East Tennessee State University
\end{abstract}

\begin{abstract}
In Partial Fulfillment
of the Requirements for the Degree

Doctor of Education
\end{abstract}

by

Joseph D. Keith

May 1996

Reproduced with permission of the copyright owner. Further reproduction prohibited without permission. 
UMI Number: 9623476

UMI Microform 9623476

Copyright 1996, by UMI Company. All rights reserved.

This microform edition is protecied against unauthorized copying under Title 17, United States Code.

\section{UMI}

300 North Zeeb Road

Ann Arbor, MI 48103 


\section{APPROVAI}

This is to certify the Advanced Graduate Committee of Joseph D. Keith

met on the

19th day of March 1996.

The committee read and examined his dissertation, supervised his defense of it in an oral examination, and decided to recommend that his study be submitted to the Graduate council, in partial fulfillment of the requirements for the degree of Doctor of Education in Educational Administration.

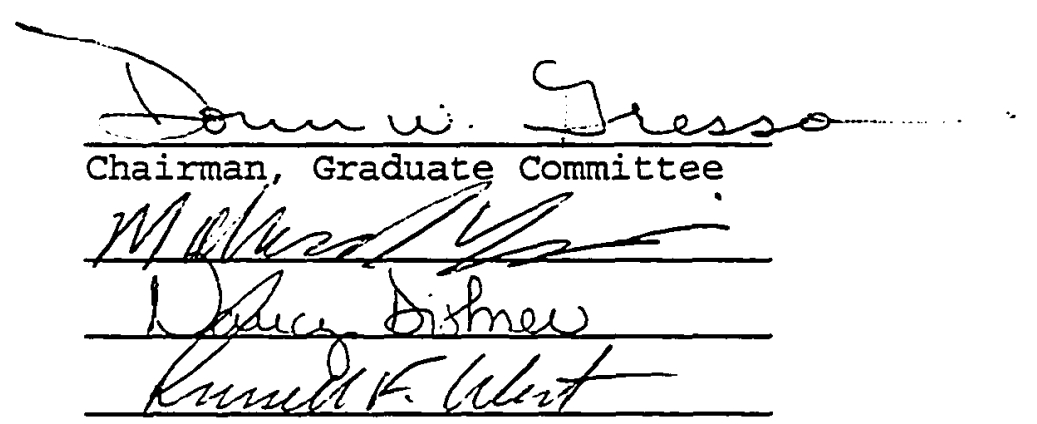

Signed of behalf of the Graduate Council

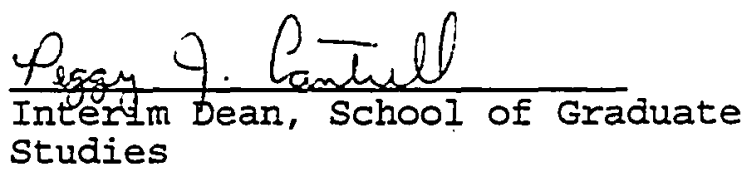




\author{
ABSTRACT \\ THE RELATIONSHIPS AMONG LEADERSHIP BEHAVIORS OF \\ LEADERS IN TRAINING ORGANIZATIONS, TRAINING \\ METHODS, AND ORGANIZATION PROFITABILITY
}

by

Joseph D. Keith

Business organizations are decreasing funding for training. The problem investigated in this study was to determine if there was a relationship among the leadership behavior of training leaders, the use of newer methods of training, and organizational profitability.

A sample of 57 organizations from the Fortune 500 was surveyed to determine leadership behavior and the use of newer methods of training. The Leadership Practices Inventory was used to measure leadership and the Affective Communication Test was used to measure charisma. Profitability data were obtained from the literature. Return on assets, return on equity, the Moody's Corporate Bond Rating, and the Standard and Poor's Opinion were used as profitability measures. Correlation and regression analyses were used to analyze the data.

No relationships were shown between leadership behaviors and training methods or between leadership behaviors and profitability. A positive relationship was shown between the number of newer training methods used and organization profitability as measured by return on assets. The following were the newer training methods: (a) accelerated learning, (b) case study methods, (c) computerbased training, (d) experiential exercises/games/ simulations, (e) interactive video instruction, (f) multimedia, (g) non-computerized self-study, (h) problembased learning, and (i) video teleconferencing. 
INSTITUTIONAI REVIEW BOARD APPROVAI

This is to certify that the following study has been filed and approved by the Institutional Review Board of East Tennessee State University.

Title of Grant or Project The Relationship Among Leadership Behaviors of Leaders in Training Organizations, Training Metheds, and organization Profitability

Principal Investigator Joseph D. Keith

Department Educational Leadership and Policy Analysis

Date Submitted May 20,1995

Institutional Review Board, Chairman

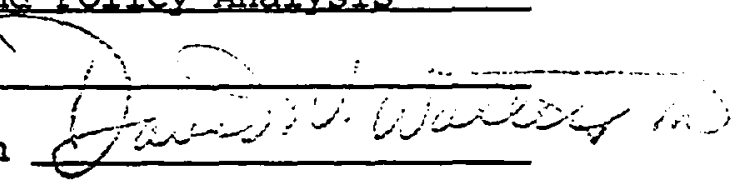


DEDICATION

This dissertation is dedicated to my wife susan, my parents, Ray and Margie, and my children Paul and Sarah. 


\section{ACKNOWLEDGEMENTS}

My sincere appreciation is extended to my doctoral committee chairman, Dr. Donn Gresso, for his time, guidance, encouragement, and kindness that made this study possible.

A special thanks is expressed to the current members of my doctoral committee: Dr. Nancy Dishner, Dr. Russell West, Dr. Mahmoud Yasin. Thanks is also expressed to former members of my committee: Dr. Earnest Bentley, Dr Robert McElrath, and Dr. Charles Burkett. They all assisted in the completion of the dissertation and contributed to my professional growth.

I am grateful to Eastman Chemical Company management for tuition aid and support and encouragement.

To my faithful wife, Susan, I will be eternally indebted for your faith, patience, love, and assistance during this and other endeavors. She proofread the manuscript of the dissertation.

Ms Sharon Barnett is acknowledged for her kindness and helpfulness curing my time in the ELPA Department.

A final word of thanks is expressed to Dr. Barry Posner for his kindness and support by letting me use and reproduce the Leadership Practices Inventory for this study. 
Page

APPROVAI . . . . . . . . . . . . . . . . . .

ABSTRACT .. . . . . . . . . . . . . . . . iii

INSTITUTIONAI REVIEW BOARD . . . . . . . . . . . . iv

DEDICATION . . . . . . . . . . . . . . . . . . . . V v

ACKNOWLEDGEMENTS . . . . . . . . . . . . . . . . . . vi vi v v v

LIST OF TABLES . . . . . . . . . . . . . . . . . xii

Chapter

1. INTRODUCTION ................ . . . 1

Statement of the Problem . . . . . . . . 3

Purpose of the Study . . . . . . . . . . 4

Hypotheses . . . . . . . . . . . . . 4

Significance of the Problem . . . . . . 5

Iimitations . . . . . . . . . . . 6

Definitions . . . . . . . . . . . . 6

Overview of the Study . . . . . . . . . . 8

2. REVIEW OF RELATED IITERATURE . . . . . . . . 9

Introduction . . . . . . . . . . . 9

Leadership Behaviors . . . . . . . . . 9

Training Department Leadership Behavior . . 10

Challenging the Process . . . . . . . 11

Inspiring a Shared Vision . . . . . 13

Enabling Others to Act . . . . . . . 15

Modeling the Way . . . . . . . . 16

Encouraging the Heart . . . . . . . 17

vii 


\begin{tabular}{|c|c|c|c|c|c|c|c|c|c|c|c|c|}
\hline Charisma . & . . . & - & - . & & & - & - & - & - & - & & \\
\hline Summary . . & . . . & - & - & & - & - & - & - & - & - & & \\
\hline raining Organiz & ations & - & - & & - & - & $\cdot$ & - & - & - & & \\
\hline Summary . . & . . . & - & - & & • & - & - & $\cdot$ & - & $\bullet$ & & \\
\hline raining Methods & ; . . . & - & - & & - & - & - & - & - & - & & \\
\hline Accelerated & Learn & ing & & & • & $\bullet$ & $\cdot$ & - & - & - & & \\
\hline Case Study I & Method & & - & & - & - & - & - & - & - & & \\
\hline Computer-bas & sed Tr & ain & ins & & - & - & - & 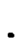 & - & - & & \\
\hline Experientia. & I Exer & cis & es/ & $G$ & $2 \mathrm{tt}$ & es & & & & & & \\
\hline Simulat & tions & - & - & & - & • & - & - & - & - & & \\
\hline Interactive & Video & In & st & su & at & & $n$ & - & • & - & & \\
\hline Multimedia & . . . & - & - & & - & $\cdot$ & - & - & - & - & & \\
\hline Non-computes & rized & Sel & & & do & & & 0 & $r a$ & $\mathrm{~ms}$ & & \\
\hline Problem-base & sed Lea: & & & &  & $\cdot$ & - & $\cdot$ & - & - & & \\
\hline Video Telecc & onfere & 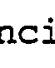 & & & • & - & - & - & - & $\bullet$ & & \\
\hline Summary - . & . . . & - & - & & • & • & $\bullet$ & • & $\cdot$ & $\cdot$ & & \\
\hline Profitability . & $\cdot \cdot$ & • & $\cdot \cdot$ & & & & - & $\cdot$ & - & - & & \\
\hline
\end{tabular}

The Relationship between Leadership

Behavior and Organization

Performance . . . . . . . . . . 33

Summary . . . . . . . . . . . . 35

The Relationship between Training Methods and Organization Performance . . . . 35 Summary . . . . . . . . . . . . 37

Overall Summary . . . . . . . . . . 37

3. METHODS ..................... . . 38

viii 
Sample Selection and Data Collection . . . . . 38

Research Design . . . . . . . . . . . . 39

Instrumentation . . . . . . . . . . . . . . 41

Leadership Behaviors Used . . . . . . . . 41

Leadership Practices Inventory . . . . 41

Statistical Analysis of the LPI . . . . 43

Validity of the LPI . . . . . . . . 43

Affective Communication Test . . . . . 44

Statistical Analysis of the ACT . . . . 44

Validity of the ACT . . . . . . . . 45

Training Methods Used. . . . . . . . . 45

Demographic Data . . . . . . . . . . 46

Profitability . . . . . . . . . . . . 46

Analysis . . . . . . . . . . . . . . 47

Summary . . . . . . . . . . . . . . . 48

4. ANALYSIS . . . . . . . . . . . . . . . . 49

Introduction . . . . . . . . . . . . . . . . 49

Sample Returns . . . . . . . . . . . . . . 49

Demographic Data . . . . . . . . . 50

Analysis . . . . . . . . . . . . . . 50

Relationship between Leadership and Method of

Training . . . . . . . . . . . . 66

Relationship between Leadership and

Profitability .. . . . . . . . . . 66

Relationship between Method of Training and

Profitability . . . . . . . . . . 70

ix

Reproduced with permission of the copyright owner. Further reproduction prohibited without permission. 
Relationship between Demographics and

Profitability . . . . . . . . . . 84

Regression Analysis on ROA . . . . . . . . . 89

Summary . . . . . . . . . . . . . . . . 89

5. FINDINGS, CONCLUSIONS, AND RECOMMENDATIONS . . . . 91

Introduction . . . . . . . . . . . . . . 91

Findings . . . . . . . . . . . . . . . 91

Discussion of Findings . . . . . . . . . . . . 92

Sample . . . . . . . . . . . . . 92

Leadership and Method of Training . . . . . 93

Leadership and Profitability . . . . . . 93

Method of Training and Profitability . . . . 94

Demographics and Profitability . . . . . 96

Conclusions . . . . . . . . . . . . . . . 96

Recommendations . . . . . . . . . . . 97

REFERENCES .................... 100

APPENDICES . . . . . . . . . . . . . . . . . 110

A. Letter for Pilot Study . . . . . . . . 111

B. Letter for Human Resources

Vice-President . . . . . . . . . . . 113

C. Table of Random Numbers . . . . . . . 116

D. Post Card for Human Resources

Vice-Presidents . . . . . . . . . . 118

E. Letter for Training Leader. . . . . . . 120

F. Demographic Information .. . . . . . . 123

G. Training Methods Used . . . . . . . . 125

$\mathbf{x}$ 
H. IPI-Self.................. 129

I. ACT-Self............... . . 133

J. Informed Consent Form . . . . . . . . 135

K. Letter for Training Subordinate . . . . . 138

I. LPI-Other . . . . . . . . . . 140

M. ACT-Other . . . . . . . . . . . 144

N. Letter from Dr. Barry Posner . . . . . . . 146

o. Letter from Institutional Review Board . . 148 VITA ...................... 150 


\section{IIST OF TABLES}

Table

Page

1. Reasons for Not Participating in the Study . . 51

2. Demographic Data on Sample (Frequencies) . . 52

3. Demographic Data on Sample (Means and

Standard Deviations . . . . . . . . . . 54

4. Number of Newer Training Methods Used . . . . 55

5. Leadership Practices Inventory Scores for

Self................. . . 57

6. Leadership Practices Inventory Scores for

Other . . . . . . . . . . . . 58

7. Affective Communication Test Scores for Self and other ............ 59

8. ROA and ROE Profitability Data . . . . . . 59

9. Moody's Corporate Bond Rating Profitability

Data............ . 60

10. S\&P Opinion Profitability Data . . . . . . 61

11. "Z" Test for Sample Compared to Population

for Number of Employees and Current

Revenue .............. 62

12. Comparison of Sample and Population by

Industry Category . . . . . . . . . . 63

13. Correlation of Leadership Practices

Inventory-Self to Number of Newer

Training Methods . . . . . . . . . . . 67

14. Correlation of Leadership Practices

$x i i$ 
Inventory-Other to Number of Newer Training

Methods . . . . . . . . . . . . 68

15. Correlation of Affective Communication Test

for Self and Other to Number of Newer

Training Methods . . . . . . . . . . 69

16. Correlation of Leadership Practices

Inventory-Self to Return on Assets . . . . . 71

17. Correlation of Leadership Practices

Inventory-Other to Return on Assets . . . . . 72

18. Correlation of Affective Communication Test

for Self and other to Return on Assets. . . . 73

19. Correlation of Leadership Practices

Inventory-Self to Return on Equity . . . . . 74

20. Correlation of Leadership Practices

Inventory-Other to Return on Equity . . . . 75

21. Correlation of Affective Communication Test

for Self and Other to Return on Equity . . . 76

22. Correlation of Leadership Practices

Inventory-Self to Moody's Bond Rating . . . . 77

23. Correlation of Leadership Practices

Inventory-Othe: to Moody's Bond Rating . . . 78

24. Correlation of Affective Communication Test

for Self and Other to Moody's Bond

Rating . . . . . . . . . . . . . 79

25. Correlation of Leadership Practices

Inventory-Self to S\&P Opinion . . . . . . 80

xiii

Reproduced with permission of the copyright owner. Further reproduction prohibited without permission. 
26. Correlation of Leadership Practices

Inventory-Other to S\&P Opinion ....... 81

27. Correlation of Affective Communication Test

for Self and Other to S\&P Opinion . . . . . 82

28. Comparison of Newer Training Methods to ROA, ROE, Moody's Bond Rating, and S\&P Opinion .............. . 83

29. Correlation of Age, Gender, Education Level, No. of Employees in Training Organization, and No. of Years in Current Position to Return on Assets . . . . . . . . . 85

30. Correlation of Age, Gender, Education Level, No. of Employees in Training Organization, and No. of Years in Current Position to Return on Equity . . . . . . . . . 86

31. Correlation of Age, Gender, Education Level, No. of Employees in Training Organization, and No. of Years in Current Position to Moody's Bond Rating . . . . . . . . 87

32. Correlation of Age, Gender, Education Level, No. of Employees in Training Organization, and No. of Years in Current Position to S\&P Opinion . . . . . . . . . . . .

33. Regression Analysis of Leadership Practices Inventory Totals, Affective Communication Test, and Number of Newer Training Methods

$$
\text { xiv }
$$


on Return on Assets . . . . . . . . . . 90 
CHAPTER 1

INTRODUCTION

Leadership behaviors in American businesses have been in continual change. The most current leadership behaviors have been emphasizing change, challenging the status-quo, visioning, moving towards a learning organization, forming to an information organization, championing empowerment, modeling systems, and constructing mental models (Bennis, 1989; Byham, 1988; Covey, 1990; Kotter, 1990; Senge, 1990). Leadership in training organizations has also undergone change. Training leaders have been emphasizing decentralization, coaching, facilitation, and teamwork. Their primary focus has been on producing results, focusing on bottom line behaviors, being held accountable for business results, participative work environments, employee teams, and facilitating change ("Designing a value-added HR organization", 1993; Longman, 1988; Meister, 1994; Witkin, 1992). Methods of delivering training have changed from principally lecture, video, and one-to-one training to greater use of games, simulations, computer-based training, interactive video, multimedia, and experiential learning (Froiland, 1993; Gordon, 1990; Meister, 1994). Training, much the same as any other part of a profit-making organization, must contribute to the bottom line. 
Covey (1990) stated that corporations must focus on economic well-being and that jobs are to produce wealth. The training organization in a company must contribute to this well-being. The often heard quote is, "In tough times, training is the first thing to get cut" (Lee, 1992, p. 31). In $1991,59 \%$ of the budget cutting organizations surveyed by Training magazine cut the training budget (Lee, 1992). In 1992, $60 \%$ of organizations participating in the same survey cut training budgets. Hassett (1992) wrote that the most compelling demonstration of a training program's effectiveness is its effect on the bottom Iine or ROA (return on assets or investment). Malcolm (1992) suggested that the company's executives are scheming to cut costs and they are looking at the training department.

The most common method of determining a company's success is its measure of profitability. Profitability is usually measured by ROA which is determined by profits after taxes divided by total assets (Stoner \& Wankel, 1986). Certain questions can be asked: Does a training department with training leaders who use new, empowered leadership behaviors contribute to profitability? Does a training department with training leaders who use new, empowerea leadership behaviors use the more modern training methods? Does a training departinent which uses the more modern training methods contribute to a company's profitability? 


\section{Statement of the Problem}

If training organizations are to survive, they must contribute to profitability. Many studies have tried, usually unsuccessfully, to show a direct link between specific training courses and organization profitability (Fitz-enz, 1994; Hassett, 1992; Pine \& Tingley, 1993). One problem is that some organizations are decreasing their emphasis on training. What are organizations trying to find out regarding training? Should organizations give training more or less emphasis? Do empowered leadership strategies of training leaders contribute to organization profit? Does the use of the newer training methodological strategies contribute to organization profit. Given that organizations are trying to increase profitability, can a relationship be shown between either or both the leadership behavior of training leaders and the training methodological strategies that would contribute to organization profit? If such a relationship could be shown, then these strategies could be emphasized. 


\section{Purpose of the study}

The purpose of this study was threefold:

1. to determine if there was a relationship between leadership behaviors of leaders in training organizations and organization profitability;

2. to determine if there was a relationship between leadership behaviors of leaders in training organizations and training methods used; and

3. to determine if there was a relationship between training methods used and organization profitability. The data collected would contribute to the body of knowledge regarding leadership behaviors, training methods, and profitability.

\section{Hypotheses}

The following null hypotheses were formulated for this study.

Hypothesis 1. There is no significant relationship between leadership behaviors of leaders in training organizations and method of training.

Hypothesis 2. There is no significant relationship between leadership behaviors of leaders in training organizations and organization profitability.

Hypothesis 3 . There is no significant relationship between method of training and organization profitability. Hypothesis 4. There is no significant relationship between demographic data such as: age, gender, race, 
education level, number of employees in the training department, and number of years in current position and organization profitability.

\section{Significance of the Problem}

IBM once trained each employee for more than 40 hours per year (Peters, 1987), but now IBM has halved its costs, trainers, and curriculum, and has cut student hours by $40 \%$ (Gerber, 1994a). Witkin (1992) reported that training budgets and staff have been slashed. Dixon (1989) stated that training has low status in the organization due to lack of management support. The importance of training on the bottom Iine of corporations needs to be determined. If a relationship could be shown between training leadership styles and training methods and the corporation's profitability, training, through the use of proper strategies and methods, would be given more emphasis. This study could help training leaders determine the proper leadership style and the proper method of training that would contribute to the organization's profitability.

This study will determine if there are relationships between training leadership behaviors, training methods, and profitability. Even if such relationships are established, there is no proof of cause and effect. It will be assumed that better training leadership and newer methods of training contribute to increased profitability, but there will not be any method to prove this assumption. 


\section{Limitations}

1. Participants in this study were limited to a sample of 57 training leaders and their subordinates from 486 corporations in the 1994 Fortune magazine 500 listing of $U$. S. corporations ("The Fortune 500", 1994).

2. The study was limited to the training leaders' self perception of leadership behavior.

3. The study was Iimited to the training leaders' subordinates' perceptions of the training leaders' leadership behavior.

4. The study was Iimited to specific training methods shown to be new or innovative.

5. The findings of this study may not be applicable to small businesses, not-for-profit organizations, or public institutions.

\section{Definitions}

The following terms were defined for use in this study:

Ieadership: the process of getting others to want to do something that the leader is convinced should be done (Kouzes \& Posner, 1987). Leadership was measured partly by the Leadership Practices Inventory which contains five leadership practices.

Charisma: leadership was also measured by charisma which was defined as the special ability and desire to inspire, lead, or elicit the devotion of others (Friedman, Prince, Riggio, \& DiMatteo, 1980). 
Management: Stoner and Wankel (1986, p. 692) define management: "The process of planning, organizing, leading, and controlling the work of organization members and of using all available organization resources to reach stated goals."

Profitability: measured by return on assets (Stoner \& Wankel, 1986), return on equity, Moody's Corporate Bond Rating, and S\&P Opinion.

$\underline{R O A}$ : return on assets or investments.

ROE: return on equity.

Bond Rating: Moody's Corporate Bond Rating (Moody's, 1995).

S\&P Opinion: Standard \& Poor's Stock Appreciation Ranking System (Standard \& Poor's, 1995).

Training: the role performed by an organization assigned the specific responsibility and authority for educating, training, and development of its employees (Craig \& Bittel, 1967).

Training Leader: the leader, manager, or superintendent of a training department who determines the need for, develops, delivers, and evaluates training.

Training Method: the instructional method used to deliver training (Froiland, 1993). 


\section{Overview of the Study}

The study was organized into five chapters:

Chapter 1 contains the introduction, statement of the problem, purpose of the study, hypotheses, significance of the problem, limitations, definitions, and organization of the study.

Chapter 2 contains a review of the literature. This review is divided into eight major categories:

Introduction, (2) An Overview of Leadership Behaviors,

Leadership Behavior of Training Leaders, (4) Training

Organizations, (5) Training Methods, (6) Profitability, (7) The Relationship between Leadership Behavior and Organization Performance, and (8) The Relationship between Training Methods and Organization Performance.

Chapter 3 contains the selected research methodology and the instrumentation used in the study.

Chapter 4 presents the findings and the analysis of the data.

Chapter 5 includes a summary of the study with conclusions and recommendations. 
CHAPTER 2

REVIEW OF RELATED IITERATURE

\section{Introduction}

This review begins with an overview of leadership behaviors and training department leadership behaviors. Training organizations and training methods are reviewed next.

\section{Leadership Behaviors}

Although Bennis (1989, p. I) stated, "leadership is like beauty: it's hard to define, but you know it when you see it," many definitions of leadership abound. Hersey and Blanchard (1982, p. 83) defined leadership as, "the process of influencing the activities of an individual or a group in efforts toward goal achievement in a given situation." Burns (1978) stated:

"Leadership is the reciprocal process of mobilizing, by certain persons with certain motives and values, various economic, political, and other resources, in a context of competition and conflict, in order to realize goals independently or mutually held by both leaders and followers." (p. 425)

Drucker (1954, pp. 159-160) suggested, "Leadership is the lifting of a man's vision to higher sights, the raising of a man's performance to a higher standard, the building of a man's personality beyond its normal limitations." Kotter 
(1990, p. 3) used leadership to refer "to a process that helps direct and mobilize people and their ideas." Kotter further stated that leadership can be described as establishing direction, aligning people, and motivating and inspiring. Kouzes and Posner (1987) concluded that there are five fundamental practices that enabled leaders to get extraordinary things done. These practices and accompanying behaviors are: (a) challenging the process that includes searching for opportunities and experimenting and taking risks, (b) inspiring a shared vision that includes envisioning the future and enlisting others, (c) enabling others to act including fostering collaboration and strengthening others, (d) modeling the way that includes setting the example and planning small wins, and (e) recognizing individual contributions and celebrating accomplishments.

\section{Training Department Leadership Behavior}

Training can be considered an important function in most organizations. Meister (1994) reported that the average time a worker for one of the Fortune 500 Companies spends in training is two-and-one-half percent of the total work time. The leader of the training department and the leaders of the organization want that time to be spent productively and directed toward achieving the goals of the organization. 
MCDougall (1993) concluded that the training manager's or leader's job is fundamentally concerned with planning, organizing, controlling, and developing the training function. Nilson (1991) reported that the training leader coordinates and facilitates training. The job may not be that easy because Sloman (1994) reported that training managers live in a state of intellectual confusion. The managers are trying to link training with the company strategy, are trying to determine how training relates to company culture, and are trying to help the company become a learning organization.

Training managers exhibit the same leadership behaviors in carrying out their jobs as do leaders in general.

\section{Challenging the process}

Kouzes and Posner (1987) wrote that leaders challenge the process by searching for opportunities to change the status quo and they experiment and take risks. Max DePree (1992) recommended that a leader should challenge constraints and create a culture for change. Employees will follow a leader who makes meaningful changes connected to a strategy. Change should not be pursued for its own sake, but change is worth the risk if it moves the organization closer to the mission and vision. Tom Peters (1987) wrote that leaders must become obsessive about change. Peters recommended that employees be evaluated on their love of 
change. Kotter (1990) wrote that the primary function of leadership is to produce change.

Training is a process that calls for a change of behavior. Witkin (1992) recommended that the training manager of the nineties should be a change agent whose mission is to clarify, interpret, advise, facilitate, and instruct. One way that this may be done is for the training department to experience fundamental change to provide value-added services to the organization (Fitzgerald, 1993). Gerber (1994b) suggested that the training department may have to be re-engineered to carry out its new mission. The training department must serve as a learning laboratory for experimenting with new approaches and practices for the design and delivery of both formal and informal learning initiatives (Meister, 1994). The training manger can not be too attached to any one training methodology (Witkin, 1992). The training manger's job will be to help the organization change, to develop new systems, to change the culture and structure of the company, and to help position the company for future growth. (Gordon, 1986). One of the most recent changes in the training area is the establishment of corporate colleges or universities as is being done at Corning, Saturn, Motorola, Xerox, and IBM (Meister, 1994). 
Inspiring a Shared Vision

Kouzes and Posner (1987) stated that leaders inspire a shared vision by envisioning the future and enlisting others in the dream. Cunningham and Gresso (1993) wrote:

"The visionary model is necessary for appropriate team dynamics to develop, and to minimize the unproductive characteristics of defensiveness and fear. It focuses on a collective view of the ideal, and everyone's efforts are focused on creating that ideal. The visionary model allows team members to feel comfortable discussing where effort is required in order to achieve the vision. The focus is on specific areas that need to be addressed if the vision is to be realized, rather than on tearing down or berating what has already been done. The visionary model inspires the team to work toward achieving an ideal." (p. 43)

Peters (1987) suggested that developing a vision and living it vigorously are essential elements of leadership. Effective leadership is marked by a vision of how the organization wishes to make its mark. The leader should frequently discuss and promote the vision to all levels of employees. Kotter (1990) recommended that a leader should establish direction with a vision which describes key aspects of the organization in the future and a strategy for achieving the vision. The leader must get employees lined up behind the vision. A major communication challenge for 
leaders is to get employees to understand and believe the vision. Covey (1990) concluded that the best way to get employees to share in the vision is to get employees involved in the process of creating the vision. The process of creating is more important than the actual document. Senge (1990) concluded that a shared vision is a force of impressive power in people's hearts. The vision is shared when all employees have the same picture and are committed to everyone having the vision. A vision will come from someone's personal vision and may take a long time to emerge. Although the leader will want commitment to the vision, many employees will often remain compliant. A leadership challenge is in changing employees' compliance to commitment.

One of the new missions for a training department will be to provide all levels of employees with a common shared vision of the company and its values and culture. Within the training department there should be a set of comprehensive goals with a mission statement for training and education which would show the reason for the existence of the training department over a long time perspective of 10 years or more (Longman, 1988; Pittman, 1987). One of the many roles of the training manager is to develop and articulate the training strategy and promote the training culture throughout the training department and the whole company (Sloman, 1994). 
Enabling others to Act

Kouzes and Posner (1987) stated that leaders enable others to act by fostering collaboration to build spirited teams and by strengthening others making them feel capable and powerful. Cunningham and Gresso (1993) wrote that true empowerment enables people to discover, develop and achieve their potential. People need to become intrinsically motivated and work for the rewards of the organization, but also work from the heart. Covey (1990) suggested four conditions for empowerment: (a) win-win agreement, (b) self-supervision, (c) helpful structure and systems, and (d) accountability. A win-win agreement is a psychological contract between a manager and a subordinate that represents a clear understanding and commitment regarding expectations in: (a) desired results, (b) guidelines, (c) resources, (d) accountabilities, and (e) consequences. After a win-win agreement is established, people can supervise themselves in terms of that agreement. Helpful organizational structures and systems include strategic planning, company structure, job design, communication, budgeting, compensation, information, recruitment, selection, placement, training, and development.

If the training department is training others in empowerment, then the training manager should be practicing empowerment. Longman (1988) recommended that the training manager must foster a participative work environment and 
empower employee performance teams. One way to do this is to empower employees who are not in the training department to do training (Staff, 1991, August). This practice can leverage the effect of the training department more than could be achieved with the training department staff. The training manager should be managing training in the organization, not just managing the training department.

\section{Modeling the Way}

Kouzes and Posner (1987) wrote that leaders model the way by setting the example for others and by planning small wins. Leaders can unravel bureaucracy, put up signposts, and create opportunities for victory. Peters (1987) recommended that leaders set the example about what is important in the organization by what they spend their time on. A leader should practice visible management and get out of the office at least two-thirds of the time. This time should be spent talking with and listening to employees, suppliers, and customers. DePree (1992) suggested that a leader sets the example for openness and imagination and acceptance. A leader shows by example how to live constructively with eccentricity and how to use creative people effectively.

The training leader should set the correct example for others in the organization. Bellman (1981) recommended that the training manager be a model for clients. Whatever the training department is teaching, e.g. performance appraisal, 
meeting skills, etc., the training manager should model those behaviors. The training manager should not ask clients to try any new ideas and innovations without first trying them in the training department. As clients see training use and practice the innovations, the clients will be more likely to use them also. The training manager should also set the example by balancing working long hours with personal life, by exhibiting humility, by demonstrating a sense of humor, by being open to new ideas, and by networking with others, especially vendors and clients (Staff, 1991, June).

\section{Encouraging the Heart}

Kouzes and Posner (1987) wrote that leaders encourage the heart by recognizing contributions and by celebrating accomplishments so that everyone feels like a hero. Aubrey Daniels (1989) recommended the use of positive reinforcement to motivate employees. Positive reinforcement is the only consequence that maximizes performance. The best reinforcers are personalized, immediate, specific, and sincere. In addition to reinforcing behavior, leaders should reward good results with celebrations. Usually organizations that take time to celebrate accomplishments are high-performing organizations.

The training leader should encourage others, should give positive recognition, and should celebrate accomplishments. Mitchell (1993) emphasized the importance 
of the training leader in giving positive recognition to subordinates to motivate them. Training managers should always look for appropriate ways to reward and recognize instructors whether they are teaching classes or performing other duties (Staff, 1991, December).

\section{Charisma}

In 1947, weber wrote that another type of authority that leaders have is charisma (Hoy \& Miskel, 1991). This charisma rests on devotion to an extraordinary individual who is a leader by virtue of the followers' personal trust or by exemplary qualities of the leader. This authority is nonrational, affective, or emotional and rests heavily in the leader's personal qualities and characteristics. Kotter (1990) wrote that charisma is the attribute most important to being a good leader and motivator. Charisma comes from heredity and early personality formulation. Hersey and Blanchard (1982) wrote that charisma can better be understood as human expressiveness and expressions of warmth and friendship. Charisma is a magnetic effect that comes from an animated, strong, attractive person who has an inspiring personality.

Richardson and Thayer (1993) wrote that although traditionally charisma has been viewed as an inherited trait, charisma can be developed. To develop charisma, a leader must follow a specific process of maintaining optimism, of expressing passion, of demonstrating whole body 
communication, of drawing others in, and of inspiring appropriate emotions in others. Bryman (1992) pointed out that the only personal feature important in charismatic leadership is the ability of the leader to be a powerful speaker.

Pauchant (1991) stated that most of the past research on charisma has focused on the charismatic leader's own attributes. The nature of the followers' own perception and the interpersonal field established between leaders and followers is also of importance. Nonverbal expressiveness is now thought to be a component of political charisma (Friedman, Prince, Riggio, \& DiMatteo, 1980). Charisma can be measured better by measuring the leader's nonverbal communications than by describing the leader's physical traits.

Summary

Training is an important and vital component of most organizations. The training leader's job can be viewed in the traditional context of planning, organizing, and controlling, or it can be viewed in the Kouzes and Posner model. Much of the referenced literature fits into the Kouzes and Posner model. Training will be defined in the next section.

\section{Training Organizations}

Training has previously been defined as the role performed by an organization assigned the specific 
responsibility and authority for educating, training, and development of its employees (Craig \& Bittel, 1967). Gardner considered training as a means in achieving organizational effectiveness by management communicating policies and programs, specifying new program directions, overcoming resistance to change, and by providing the required skills and knowledge (Jasaitis, 1992). A more common definition of training is that it is the teaching, instruction, drill, or discipline by which powers of the mind or body are developed in a particular skill or group of skills in a profession or occupation (Webster's Third New International Dictionary of the English Lanquage, 1966). Training is usually considered instruction for a current job (Mitchell, 1993). Mitchell further wrote that one of the main functions of training is to change behavior. Gayeski (1993) listed various other names for a training department such as "information resources," "information and instruction," strategic communications," "corporate performance," "information management," or "the communications department." A different name may cause different perceptions in the training organization's clients.

\section{Summary}

The term training was defined in various ways. Several possible other names for training were listed. The 
different training methods will be reviewed in the next section.

\section{Training Methods}

Training methods have previously been defined as the instructional methods used to deliver training (Froiland, 1993). There are many types of training methods and these methods have changed over time with newer methods replacing older ones. Training magazine has been conducting an annual survey on training for several years (Froiland, 1993; Gordon, 1990). This survey shows the percentage of companies using various training or instructional methods. A comparison of the survey from 1993 with the survey from 1990 shows training methods used by the surveyed companies that were not Iisted in 1990. These newer methods are multimedia, interactive video, and computer-based training. Several methods: such as, games, simulations, case studies, non-computerized self-study programs, and video teleconferencing were used by a larger percentage of companies surveyed in 1993 as compared to 1990. Meister (1994) listed a number of newer training methods such as multimedia and experiential learning exercises (simulations) that are being used in corporate quality universities. Doyle (1991) listed accelerated learning and interactive video instruction as newer innovations in training. Malcolm (1992) listed problem-based learning as one of the newer methods of training. 
One reason for going to some of the newer methods is that there are several disadvantages of the traditional lecture-based classroom training (Gerber, 1994b). One disadvantage is the cost of the employee's and the instructor's time in the class and the travel time involved if the employees are not located at the training site. Another disadvantage is that each employee receives the same amount of training whether needed or not. Classroom training is considered expensive and inefficient. One training director stated, "We don't have the luxury of using the old methodologies any more," (Gerber, 1994b, p. 28).

Carnevale, Geiner, and Meltzer (1990) recommended choosing a training method based on identifying the kind of learner performance to be developed related to the actual performance on the job. If presentation methods are used, they should always be followed by another method that involves the learner. Another factor to consider is the amount of participant involvement. A lecture would have low participant involvement, but a case study would have higher involvement.

Several of the newer training methods are explained in more detail.

\section{Accelerated Learning}

Accelerated learning (AI) is a training approach also known as integrative learning (IL) or super learning (Bretz \& Thompsett, 1992). AI stresses the learning environment 
and creates environmental conditions believed to maximize learning. The traditional barriers to learning are eliminated so students can use more of their cognitive potential and experience greater learning and retention. The AL approach is a combination of physical relaxation, mental concentration, guided imagery, suggestive principles, and baroque music. Some of the supportive components used are comfortable surroundings, music, rhythmic mnemonics, games, stories, poetry, background posters and peripherals, and group interactions. Student performance is enhanced through self-monitoring, data feedback, and positive reinforcement.

Benefits of AI such as, increased competency, higher test scores, better job performance, and reduced training times are claimed by several authors (Cournoyer, 1991; Froiland, 1983; Gill \& Meier, 1989). Bretz and Thompsett (1992) concluded that the documentation on some of the past studies had been inadequate and that the studies had been characterized by poor research practices.

\section{Case Study Methods}

The case study method involves reporting an actual or make-believe situation, having the learners think about and analyze the case, and discussing the case with other people (Pigors \& Pigors, 1987). The case method started at Harvard Law School, spread to the wharton School of Finance and Commerce, and is now practiced in many forms. These forms 
include fictitious and abbreviated cases, labor arbitration reports, single problem cases, the incident processes, and short cases. Cases can be delivered in printed form, by audio tape, by video tape, or in Iive form (Eitington, 1984).

Some advantages of cases are that they are personal, real, and specific (Eitington, 1984). Cases promote group discussion, give and take, judgement, and understanding of human behavior. Cases also have certain disadvantages such as incompleteness, slowness, and lack of involvement of quiet learners. Cases require skilled discussion leaders who can integrate the results of the case with real job situations.

\section{Computer-based Training}

Computer-based training (CBT) was one of the first of the high technology training methods. Other names for CBT are computer-assisted instruction (CAI), computer-assisted learning ( $C A I)$, and computer-based instruction (CBI) (Gaveski, 1993).

CBT consists of interactive tutorials and simulations containing text and possibly graphics that provide training by means of a main frame computer or a personal computer (Gaveski, 1993). The trainees are presented with computer screens with information and are then asked questions. Depending on the trainee's answers, the trainee may receive 
customized feedback. The computer has the capability to maintain records of the trainee's responses and score.

Since many companies have invested so highly in technology, it is of critical importance to teach employees to use the systems (Witkin, 1992). Witkin concluded that technology does not always produce the desired results because of computer deficiencies and applications that were not "user friendly." Sometimes trainees resist CBT because the trainees are not used to learning that way (Gerber, 1994b).

\section{Experiential Exercises/Games/Simulations}

Experiential exercises, games, and simulations are used because people learn best when they are doing or engaging in the learning process (Bolt, 1990; Hitchcock, 1988). The learning takes place on three levels, physical, intellectual, and emotional (Petrini, 1990).

Hitchcock (1988) defined an instructional game as one where the primary purpose is to teach, not entertain. Instructional games should contain competition, risk, and scoring. Competition may be against other competitors, a standard, the facilitator, or other constraints. The risk involved should minimize the element of change and emphasize the trainee's ability to make a correct choice. Scoring has to be present so trainees can get feedback on performance. Meister (1994) defined sxperiential learning exercises as situations that were carefully researched in focus groups 
with employees and supervisors interacting to simulate realworld conditions. Workers learn by doing and applying these new skills in job situations. These exercises use drama and excitement to illustrate simple points of real employee issues. The exercises are designed so that the employee participants are responsible for the action. Thompson (1991) Iimited experiential training to that which is participative, interactive, rich with feedback, adapted to the changing needs of the learner, and guided by clear expectations for educational outcomes.

Experiential exercises can be outdoor adventure based or indoor types. Some business simulations resemble the board games of childhood (Bolt, 1990). Outdoor experiences may be of the wilderness type, the "high-ropes" courses, or the "low-ropes" courses (Thompson, 1991). Most of these types of experiences include some type of lecture before the exercise and extensive, in-depth debriefing afterwards (Solomon, 1993).

The objectives for these experiences may be of a general and personal nature or may be targeted towards team building (Thompson, 1991). Personal objectives include building self-esteem, developing risk taking skills, increased self-awareness, and stress management (Petrini, 1990). Group focused or team building objectives include better communications, creative problem solving, better teamwork, and improved leadership behaviors. 
The effectiveness of these experiences depend on transferring the lessons learned to on-the-job applications (Thompson, 1991). Many of these types of programs have not yet proven themselves. Another problem with these types of exercises is that certain simulations are not always appropriate in a particular situation (Solomon, 1993).

\section{Interactive Video Instruction}

Interactive video instruction (IVI) is presented on optical discs that resemble compact discs (Gaveski, 1993). The video discs are capable of storing and playing still frames, motion video, and audio. A video disc player is used which can be controlled by remote control or which can be hooked up to an external computer.

\section{Multimedia}

Multimedia is usually considered to mean, "a computer system combining text, graphics, video, animation, audio, hypertext, and data bases in one platform," (Thompson, 1994, p. 17). The usual platform is a standard IBM (International Business Machine) compatible personal computer with mouse and keyboard interfaces and a CD-ROM (compact disc-read only memory) drive. The system has memory and can react to the trainee's input. Less expensive multimedia uses CD-I (compact disc-interactive) that has considerably less capacity than CD-ROM (Gaveski, 1993). 
Hewlett-Packard cited the need for multimedia training as an alternative to traditional classroom lectures for employees who work swing or night shifts and for employees at off-site locations (Spitz, 1992). Multimedia training can be given to fill an immediate training need. There are many reports of the use of multimedia training that resulted in improved business productivity, reduced training time, increased training test scores, and reduced training costs (K. L. Ervin, personal communication, May 29, 1994). Other benefits of multimedia are remote and on-demand delivery, self-directed learning, consistent instructional materials, multisensory reinforcement, updatability, realistic simulation capabilities, and reduced production time (Pearson, 1993). Multimedia is the fastest growing of the new training technologies. Pearson (1993) estimated that investment in multimedia training would increase about eight fold from 1990 to 1996 .

Even with all of the advantages of multimedia, there have been some technical problems which have caused some of the slowness of growth (Pearson, 1993). There have been problems of incompatible platforms, slowness of response, and poor video quality. These problems are being resolved.

\section{Non-computerized Self-study Programs}

Non-computerized self-study is but one name for a type of training method that is also called individualized instruction, learner-controlled; programmed-instruction, 
self-instructional, self-paced, self-study, and self-teach training (Budd, 1987; Mitchel1, 1993; Richards, 1989). Budd (1987) defined self-instruction to include any teaching situation where students take responsibility for their own learning and make decisions about the topic of study, objectives, resources, schedule, type and sequence of activities, environment, media, learning strategy, etc. The students usually work without direct supervision, set their own pace, and may select their own activities, resources, and learning environment. These types of self-instruction may be delivered through print media and audiovisual media. Instructors are usually not present, but may act as facilitators. One of the main factors, as was done with Skinner's earlier work on programmed instruction, is the Erequent use of quizzes and practice with immediate feedback.

Some of the advantages of self-instruction are its Elexibility, consistency, mobility, effectiveness, cost savings, compatibility with adult learning principles, and focus on the learner (Budd, 1987). These programs can also provide standardized training in remote locations (Mitchell, 1993). Disadvantages include a high development time for the materials, difficulty of revision, lack of interaction with peers and instructors, and extensive planning requirements (Budd, 1987). Sometimes poorly designed self- 
instruction can be very dull and provide little motivation to learn (Mitchell, 1993).

Problem-based Learning

Bridges (1992) defined problem-based learning as an instructional strategy with the following characteristics:

"I. The starting point for learning is a problem (that is, a stimulus for which an individual lacks a ready response).

2. The problem is one that students are apt to face as future professionals.

3. The knowledge that students are expected to acquire during their professional training is organized around problems rather than the disciplines.

4. Students, individually and collectively, assume a major responsibility for their own instruction and learning.

5. Most of the learning occurs within the context of small groups rather than lectures." (p.5)

Problem-based learning has been used extensively in medical education (Bridges, 1992). This training method creates conditions that optimize the retrieval and appropriate use of formal knowledge. Students are motivated for success by many extrinsic and intrinsic motivational strategies. Malcolm (1992) stated that the application of problem-based learning to corporate education causes learning events which produce real outcomes in the real 
world. This type of learning is "learner-driven training," since the point is to give learners what they want when they need it. Each learner leaves the learning experience with a real work product. The application of the learning is built into the process and evaluation comes from examining the work products.

\section{Video Teleconferencing}

"Video teleconference training is training delivered across hundreds of miles via satellite and over short distances via local area networks," (Nilson, 1990, p. 133). This training involves a live instructor with the capacity at both ends to see and hear on video monitors. Video teleconference training is a type of media show and requires the same staging and production of any television show.

The main advantage of video teleconference training is that students at various remote sites can see and hear an instructor and other students (Nilson, 1990). The cost for excessive travel to attend classes at a local site is eliminated. The main disadvantage is the cost of the equipment and the transmission. A second disadvantage is that the broadcast may be viewed by anyone who taps into the transmitter unless special precautions are taken. Less desirable training is accomplished with one-way video with audio response, or two-way audio teleconferencing (Schaff, 1981). These types are less expensive, but do not provide the being-there feel that two-way video provides. 
Summary

Training methods were defined as the instructional methods used to deliver training. The newer, more modern methods were listed. Reasons for going to the newer methods were given. A short description of each of the newer methods was given along with advantages and disadvantages where appropriate. Profit will be reviewed in the next section.

\section{Profitability}

The profit motive is the foundation of our free-market economic system (Rachman \& Mescom, 1987). Profitability is usually measured by a ratio of profits after taxes divided by total assets which is called return on assets (ROA) (Rachman \& Mescom, 1987; Stoner \& Wankel, 1986). Profitability may also be measured by return on equity (ROE) (Rachman \& Mescom, 1987). ROE is a short term measure of the organization's vulnerability. A high value of ROE will cause owners to continue to invest in the organization. There are two other indices that give an indication of profitability. The Moody's Corporate Bond Rating indicates the investment community's confidence in the organization with respect to buying corporate bonds (Moody's, 1995). This rating provides investors with a simple system of gradation by which the relative investment risk qualities of a bond may be noted. The Standard and Poor's (1995) S\&P opinion indicates whether an investor should buy, hold, or 
sell stock. This opinion measures the short-term potential of stocks measured against a performance index. As with any other part of the organization, training must contribute to organizational performance through increased profitability. The relationship between leadership behavior and organizational performance will be reviewed next.

\section{The Relationship between Leadership Behavior and Organization Performance}

There have been a number of studies that attempted to link leadership behavior with organization performance. Bullis (1992) investigated the relationship between leader behavioral complexity and organizational performance. Behavioral complexity was defined as the ability of a leader to demonstrate competing and even contradictory behaviors in the performance of leadership roles. Bullis could not find any support of effective or ineffective leaders from companies with various levels of effectiveness. Bullis also found that leader effectiveness measures provided by superiors and subordinates were not related to organizational performance. No direct relationship between leader behavior and organizational performance was found. Hannon (1992) investigated favorable and unfavorable human resource management reputation and its effect on corporate performance. Corporate performance was measured by annual shareholder return. Only a weak relationship was found between reputation and corporate performance. 
Esrael (1992) investigated the effect of leadership styles on organizational performance of credit unions. He found no apparent perceived leadership differences between effective and ineffective leaders with respect to credit union performance.

Another study of leader attributes on organization performance was conducted by Adeyemi-Bello (1992/1993). He found that leader attribute variables may have important implications for corporate performance. None of these studies demonstrated any significant relationships between leadership behavior and organization performance.

Other studies have shown some link between various leadership behaviors and organization performance. Ostrow (1992/1993) showed a relationship between a firm's profitability and the human resource management practices. He found that certain dimensions of staffing, performance appraisal, compensation, and training and development successfully impact financial performance. He found that firms that provided more hours of training and higher levels of group oriented training had higher ROE.

In a study of the 200 largest property/casualty insurance companies in the United States, Langley (1992/1993) found that leaders with a structuralist approach and with a direct and personal approach to communicating corporate vision and goals were in the more successful insurance companies. The banking industry also showed a 
positive and significant relationship between management style and commercial bank success (Magliari, 1992/1993).

\section{$\underline{\text { Summary }}$}

The relationship between leadership behaviors and organizational performance was shown. A number of studies were cited showing organization performance could not be tied to leadership behavior and several studies were cited where there was a link between leadership behavior and organizational performance. The relationship between training methods and organizational performance will be reviewed next.

\section{The Relationship between Training Methods}

\section{and Organization Performance}

The relationship between training and an organization's performance has historically been done on a course by course basis (Fitz-enz, 1994; Montebello \& Haga, 1994; Pine \& Tingley, 1993). Early in the training literature Kirkpatrick developed a model with four levels of training evaluation, with level four being measurement of the company's return on the training investment (Pine \& Tingley, 1993). This evaluation has also been referred to as the ends, goals, results desired, or reduction of costs (Alliger \& Janak, 1989). This level of training evaluation is costly and difficult to perform and is done infrequently (Hassett, 1992). Mitchell (1993) wrote that for training to 
demonstrate its impact on organizational operations in a tangible way, training must be evaluated in terms of the bottom line and be evaluated as a return on investment. Training's impact has been shown by being responsible for specific improvements in a worker's performance that can be translated to a bottom-line improvement.

A Vice-President of Human Resource Development at Wells Fargo Bank recommended that staff functions like Human Resources Development should not claim bottom-line results for profit and loss (Zemke, 1981). Profit and loss is a line responsibility. Gordon (1986) wrote that a training manager should not take credit for bottom line results because rarely will training be the single cause of something like quarterly increase in revenue. Training can have an impact, but not be the single cause. Fitz-enz (1994) reported that there are numerous objections to trying to determine the value of training. One of these objections is that there are so many other interrelated factors that affect the financial performance of a company, it is impossible to isolate the pure contribution of training (Fitz-enz; Hassett, 1992). Fitzenz stated that executives make many decisions on a daily basis with far less analysis as to cause and effect. The value of a training program can be shown if energy, imagination, and courage are expended by those doing the evaluation. 
Summary

The relationship between training methods and organizational performance was reviewed. There have been numerous studies relating organizational performance to a given course. Some authors warned against trying to justify training in terms of ROA, while other authors said it was vital to link training to performance.

\section{Overall Summary}

The review began with a definition of leadership and a review of the basic schools of leadership and various leadership models. The Kouzes and Posner model was investigated more thoroughly with current general leadership and training leadership behaviors integrated into the model. Training and training organizations were defined and the importance of training was shown. Some of the newer training methods were described along with advantages and disadvantages. Profitability was again defined and the relationship between leadership behavior and organizational performance and between training methods and organizational performance were reviewed.

The next chapter will describe the methods used in the study. 


\section{CHAPTER 3}

METHODS

The purpose of the methods chapter is to present the population and sample, the research design, the measurement method and instruments used, and the method of analysis of the data.

\section{Sample Selection and Data Collection}

The population for this study consisted of training leaders from the top $500 \mathrm{U}$. S. industrial corporations as listed in the 1994 Fortune magazine listing ("The Fortune 500", 1994). From the 500 corporations, 486 corporations that had three years of financial data were chosen for the study

Letters were sent to the Vice-President of Human Resources in each of the 486 corporations requesting that the corporation participate in the study. The VicePresident was asked to identify the leader of the training department, and if there was more than one training department, to choose one training department leader using a table of random numbers supplied in the letter. The VicePresident was asked to send a postage-paid, self-addressed post card to the researcher giving the name and mailing address of the chosen training department leader.

The training department leader was sent a cover letter introducing the researcher and the purpose of this study as 
well as detailed instructions, the Ieadership Practices Inventory-Self (LPI-Self), five copies of the LPI-Other, the Affective Communication Test ( $\underline{A C T}$ ) for self, five copies of the $\underline{\mathrm{ACT}}$ for others, a listing of training methods, and a demographic questionnaire. The training department leader was asked to fill out the IPI-Self, the ACT for self, the listing of training methods, and the demographic questionnaire and return these to the researcher in a postage-paid, self-addressed envelope. The training department leader was asked to give the five copies of the LPI-Other and the ACT for others to five subordinates chosen using an enclosed random number table. Postage-paid, selfaddressed envelopes were also included for the others to return their questionnaires to the researcher. An offer was made to return a summary of each leader's results. One month after the initial distribution of each packet, non-responding Vice-Presidents or non-responding training department leaders were called to request the data.

\section{Research Desian}

The research design for this study included descriptive and correlational research methods. The method of collecting the data inciuded the IPI, the ACT, a listing of training methods, a demographic questionnaire, and profitability information from the current literature.

Gay (1987) described descriptive research as collecting data to test hypotheses. The descriptive study determines 
and reports the way things are. Questionnaire surveys are used to collect data. Gay described correlational research as describing in quantitative terms the degree to which variables are related and to use relationships in making predictions. The use of descriptive and correlational research designs were appropriate for testing the hypotheses in this research study because the data were coilected by questionnaire to determine the relationship among the training department leader's leadership behavior, the training methods used, and the organization profit. Selfadministered questionnaires were efficient and offered the advantage of providing contact with a large number of subjects in a geographically dispersed sample in a relatively short time frame.

Prediction studies are used to test theoretical hypotheses concerning variables believed to be predictors of a certain criteria (Gay, 1987). A combination of variables in a multiple regression study usually results in a prediction equation which will make more accurate prediction than only a single variable. A multiple correlation prediction equation was used in this study to predict profitability.

The weakness of using descriptive and correlational research design was that only relationships between the variables were discovered. No cause and effect could be determined using this type of design. Another weakness was 
that the use of this sample limited the generalizability of the results of the study to large U. S. industrial corporations.

\section{Instrumentation}

\section{Leadership Behaviors Used}

Three instruments were used to determine the leadership behavior of the training department leaders. These instruments were the IPI-Self, LPI-Other, and the $\underline{\underline{A C T}}$ which was used for both self and others.

Leadership Practices Inventory. The IPI was developed by Kouzes and Posner (1987) to measure leadership with a valid and reliable instrument. The LPI has two forms: IPISelf to be completed by the leader and IPI-Other to be completed by the leader's subordinates. Each form contains 30 items, with six items measuring each of the five leadership practices or factors: (a) challenging the process, (b) inspiring a shared vision, (c) enabling others to act, (d) modeling the way, and (e) encouraging the heart. Each item is rated on a five-point likert scale and a higher value represents greater use of a leadership behavior: (a) a value of one represents "rarely," (b) a value of two represents " once in a while," (c) a value of 3 represents "sometimes," (d) a value of 4 represents "fairly often," and (e) a value of 5 represents "very frequently,". All of 
these statements apply to the leader engaging in actions and behaviors in the 30 questions.

The LPI was designed by Kouzes and Posner (1988) based on information received from a 12 page personal best survey that contained 38 open ended questions that had been given to 550 managers. An additional 780 managers completed a shorter form. Additional information was obtained from 42 in-depth interviews with managers in middle- to senior-level positions in public and private companies. From this data, Kouzes and Posner developed the IPI. The LPI was originally completed by 120 graduate business students. Further administration of the LPI involved more than 3000 managers and subordinates. Aralysis of the data included tests of internal reliability and underlying factor structure. Initial analysis extracted five factors: (a) challenging the process, (b) inspiring a shared vision, (c) enabling others to act, (d) modeling the way, and (e) encouraging the heart. "Challenging the process" suggests that leaders are pioneers who experiment and innovate, and includes statements 1, 6, 11, 16, 21, and 26 in the LPI. "Inspiring a shared vision" indicates that leaders spend considerable effort imagining what kind of future they would like to create, and is related to statements $2,7,12,17,22$, and 27 in the LPI. "Enabling others to act" indicates that leaders gain the support and assistance of all those who must make the project work, and is associated with 
statements $3,8,13,18,23$, and 28 . "Modeling the way" encompasses the leader's behavior of setting an example, and includes statements 4, 9, 14, 19, and 29. "Encouraging the heart" includes those leadership practices of recognizing contributions and celebrating accomplishments, and includes statements $5,10,15,20,25$, and 30 .

Statistical Analysis of the LPI. The IPI has been given to over 36,000 managers and subordinates (Kouzes \& Posner, 1992). Internal consistency reliability values of coefficient alpha for the five factors range from .80 to .91 for the total sample of 36,000 offerings. Test-retest reliability on a sample of 157 graduate business school students ranged from .93 to .95 for the five factors. The LPI was analyzed for factor loading using a principal factoring method with iteration and varimax rotation. Five factors were extracted with eigenvalues greater than 1.0 which accounted for 60.2 percent of the variance. The factor loadings ranged from .556 to .753 for "encouraging the heart," from .471 to .712 for "enabling others to act," from .431 to .701 for "inspiring a shared vision," from .386 to .669 for "challenging the process," and from .367 to .580 for "modeling the way."

Validity of the IPI. The LPI has been utilized in more than nine theses and dissertations (Kouzes \& Posner, 1992). The LPI provided a statistically reliable index of visionary 
or transformational leadership. The LPI has been shown to be positively and significantly correlated to job satisfaction, organizational commitment, productivity, institutional effectiveness, performance, team effectiveness, empowerment, and inspiration.

Affective Communication Test. The $\underline{\mathrm{ACT}}$ was developed by Friedman, Prince, Riggio, and Dimatteo (1980) to measure charisma by the means of nonverbal emotional expressiveness. The $\underline{A C T}$ is a 13 -item paper-and-pencil, self-reporting test. Each item is marked on a nine-point scale from minus four to positive four, depending on the extent to which the statement is true or false. The test is scored by reversing the sign on statements $2,5,6,8,9$, and 11 (which are stated negatively) and by adding a positive 5 points to each statement so that all values are positive. This test was originally used to measure the charisma of college students. Statistical Analysis of the ACT. A value of .77 for coefficient alpha for a sample of 289 respondents was obtained for internal consistency reliability (Friedman, Prince, Riggio, \& DiMatteo, 1980). A test-retest reliability of .90 was obtained with a sample of 44 respondents on a two month time interval and a value of .91 for test-retest reliability was obtained with a sample of 38 respondents over a one week time interval. These high values indicate stability of the factors. The test developers considered the instrument to be an excellent research tool. 
Validity of the ACT. Validation of the ACT was based on judgments by associates of the test respondents (Friedman, Prince, Riggio, \& DiMatteo, 1980). Associates of 61 subjects were given a four-item bipolar rating form to rate the respondent's charisma. A significant and nontrivial relationship between the ACT self-report and the rating on the four-item form had a value of $.39, p<.01$.

\section{Training Methods Used}

The training methods used started with a listing of the 18 training methods from Training magazine's "1994 Industry Report" (Staff, 1994). In addition, the methods of accelerated learning and problem-based learning were added. This listing was used to determine which training methods the training department leader's organization was using. The 20 methods were Iisted alphabetically and the training department leader was requested to check those being used. Each method was given an operational definition to aid in understanding the question. From this listing, the following were considered to be the new methods: (a) accelerated learning, (b) case study methods, (c) computerbased training, (d) experiential exercises/games/simulations, (e) interactive video instruction, (f) multimedia, (g) non-computerized selfstudy, (h) problem-based learning, and (i) video teleconferencing. A numerical count was made of how many of the nine new methods were used by the training department 
leader's organization. The training methods used questionnaire was piloted with a sample of 10 training department leaders from business and industry in Northeast Tennessee.

\section{Democraphic Data}

Demographic data were obtained from each training department leader using a questionnaire that asked: age, gender, race, educational level, number of employees in the training department, and number of years in current position.

\section{Profitability}

Profitability was obtained for each of the corporations in the study by averaging the corporation's ROA and ROE separately for the past three years, 1992 through 1994 (Moody's, 1995, Standard \& Poor's, 1995). The Moody's Corporate Bond Rating (1995) was used for 1995. This rating ranks corporate bonds as: Aaa, for best quality bonds; Aa, for high quality bonds; A, for favorable investment bonds; Baa, for medium grade obligation bonds; $\mathrm{Ba}$, for bonds that have speculative elements; $B$, for bonds that lack characteristics of desirable investments; Caa, for bonds that are poor standing; Ca, for bonds that are highly speculative; and $C$, for bonds that are lowest rated. The S\&P Opinion lists five stars for a "buy" stock, four stars for an "accumulate" stock, three stars for a "hold" stock, 
two stars for an "avoid" stock, and one star for a "sell" stock (Standard \& Poor's, 1995). The use of various shortterm and long-term measures of profitability allowed a profile of measures similar to what is usually done in the accounting literature (Ostrow, 1992/1993). All four measures of profitability were not available for all corporations.

\section{Analysis}

Hypotheses $1,2,3$, and 4 were analyzed using the Pearson product-moment correlation analysis. The Spearman rho correlation was also calculated for comparison, but the decisions were based on the Pearson correlation coefficient. A significance level of .0125 (.05 divided by 4 ) was used since there were four hypotheses involved. This conservative significance level was chosen to prevent the "shotgun approach" as discussed by Gay (1987). The scores from the IPI-SeIf and IPI-Other were kept separate for each training department leader. Total scores from both the LPISelf and the IPI-Other were calculated and used in the analysis to give a single measure of transformational or visionary leadership (B. A. Posner, personal communication, February 2, 1996). The scores from the ACT for self and others were kept separate for each training department leader. The total number of new methods used was the measure for training methods. The average ROA and the average ROE for the last three years, the current Moody's 
Corporate Bond Rating, and the current S\&P Opinion were used as the profitability measures.

A regression analysis was performed using the two total values of the LPI scores, the $\underline{A C T}$ scores, and the number of new training methods to predict profitability using ROA as the dependent variable. All data were analyzed using the Statistical Package for the Social Sciences PC version (SPSS-PC+) .

\section{Summary}

Chapter 3 provided an overview of the population and sample, the research design, the measurement method and instruments used, and the statistical tests used in this study. Chapter 4 will discuss the results of the analysis of the data. 
CHAPTER 4

ANALYSIS

\section{Introduction}

The hypotheses presented in Chapter 1 are addressed in Chapter 4, which includes the results and analysis of the data gathered in this study. The purpose of the study was to determine the relationship among leadership behaviors of training department leaders, training methods used, and organization profitability.

\section{Sample Returns}

The pilot study using 10 training leaders from Northeast Tennessee to review the training methods questionnaire revealed that no changes were needed in the questionnaire. Nine of the 10 leaders responded to the questionnaire for a response rate of $90 \%$.

Letters were sent to the 486 Human Resources VicePresidents of the Fortune 500 corporations that had three years of financial data. Responses were received from 136 of the Vice-Presidents, either by mail or by telephone, for a response rate of $28 \%$. Of those responding, 61 initially agreed to participate in the study, but four of those subsequentiy refused, which left a sample size of 57 training leaders who participated in the study. The percentage of those participating was $12 \%$ of the original population of 486 . Of the 79 who refused to participate, 
some gave one or more reasons. These reasons are Iisted in Table 1. The most frequent reasons were "too busy" and "do not participate in surveys." No response was received from the remainder of the population after one initial letter and one follow-up telephone call.

Approximately half of the surveys returned had. responses for five subordinates as requested. Of the remainder, most had four or three subordinate responses. only four surveys were returned with less than three subordinates responding. Five of the training leaders requested anonymous feedback from the survey.

\section{Demographic Data}

The demographic data for the sample are listed in Tables 2 and 3 . Most of the training leaders were in the age category of 50 to 59 years, were male, were Caucasian, had a Master's degree, had from zero to fifty employees in the Training Department, and had been in the current job from zero to five years.

\section{Analysis}

The mean number of newer training methods used in these 57 organizations was 6.4 out of a possible 9 methods. The standard deviation was 1.984. The frequencies and percentages for number of newer training methods are presented in Table 4 . 
TABLE I

REASONS FOR NOT PARTICIPATING IN THE STUDY

\begin{tabular}{lc}
\hline Reason & Frequency \\
\hline $\begin{array}{l}\text { Too busy, no time, } \\
\text { other priorities }\end{array}$ & 21 \\
Do not do surveys & 13 \\
Downsizing, restructuring & 7 \\
No Training Department & 6 \\
No subordinates & 4 \\
No value to \\
organization \\
Employee transferred \\
$\begin{array}{l}\text { Survey too long, too } \\
\text { complicated } \\
\text { Do not agree with } \\
\text { questions }\end{array}$
\end{tabular}


TABIE 2

DEMOGRAPHIC DATA ON SAMPLE (FREQUENCIES)

\begin{tabular}{|c|c|c|c|}
\hline Demographic & Grouping & $f$ & $\%$ \\
\hline \multirow[t]{6}{*}{ Age } & $20-29$ & 1 & 1.8 \\
\hline & $30-39$ & 6 & 10.5 \\
\hline & $40-49$ & 19 & 33.3 \\
\hline & $50-59$ & 24 & 42.1 \\
\hline & Nonresponding & 7 & 12.3 \\
\hline & Total & 57 & 100.0 \\
\hline \multirow[t]{4}{*}{ Gender } & Female & 19 & 33.3 \\
\hline & Male & 38 & 66.7 \\
\hline & Nonresponding & 0 & 0 \\
\hline & Total & 57 & 100.0 \\
\hline \multirow[t]{5}{*}{ Race } & $\begin{array}{l}\text { African- } \\
\text { American }\end{array}$ & 1 & 1.8 \\
\hline & Caucasian & 48 & 84.2 \\
\hline & Other & 2 & 3.5 \\
\hline & Nonresponding & 6 & 10.5 \\
\hline & Total & 57 & 100.0 \\
\hline
\end{tabular}


TABLE 2 (CONTINUED)

\begin{tabular}{|c|c|c|c|}
\hline Demographic & Grouping & $f$ & $\%$ \\
\hline \multirow[t]{6}{*}{ Education } & High School & 1 & 1.8 \\
\hline & Bachelor's & 20 & 35.1 \\
\hline & Master's & 22 & 38.6 \\
\hline & Doctorate & 7 & 12.3 \\
\hline & Nonresponding & 7 & 12.3 \\
\hline & Total & 57 & $100.1^{2}$ \\
\hline \multirow{7}{*}{$\begin{array}{l}\text { No. employees } \\
\text { in Training } \\
\text { Department }\end{array}$} & $0-50$ & 36 & 63.2 \\
\hline & $51-100$ & 8 & 14.0 \\
\hline & $101-150$ & 2 & 3.5 \\
\hline & $151-200$ & 1 & 1.8 \\
\hline & $201+$ & 3 & 5.3 \\
\hline & Nonresponding & 7 & 12.3 \\
\hline & Total & 57 & $100.1^{\mathrm{a}}$ \\
\hline
\end{tabular}

apercentages may total more or less than 100 when rounded. 
TABIE 2 (CONTINUED)

\begin{tabular}{llll}
\hline Demographic & Grouping & f & $\%$ \\
\hline No. years in & $0-5$ & 34 & 59.6 \\
current position & $6-10$ & 11 & 19.4 \\
& $11-15$ & 4 & 7.1 \\
& $16+$ & 1 & 1.8 \\
& Nonresponding & 7 & 12.3 \\
\cline { 2 - 4 } & Total & 57 & $100.2^{\mathrm{a}}$ \\
\hline
\end{tabular}

aPercentages may total more or less than 100 when rounded.

TABLE 3

DEMOGRAPHIC DATA ON SAMPLE (MEANS AND STANDARD DEVIATIONS)

\begin{tabular}{lcc}
\hline Demographic & Mean & Standard Deviation \\
\hline Age & 47.4 & 7.080 \\
$\begin{array}{l}\text { No. employees in } \\
\text { Training Department }\end{array}$ & 49.3 & 73.403 \\
$\begin{array}{l}\text { No. years in } \\
\text { current position }\end{array}$ & 5.2 & 4.406
\end{tabular}


TABLE 4

NUMBER OF NEWER TRAINING METHODS USED

No. $\quad$ E

\begin{tabular}{lrr}
1 & 1 & 1.8 \\
2 & 2 & 3.5 \\
3 & 1 & 1.8 \\
4 & 3 & 5.3 \\
5 & 7 & 12.3 \\
6 & 14 & 24.6 \\
7 & 5 & 8.8 \\
8 & 10 & 17.5 \\
9 & 9 & 15.8 \\
Nonresponding & 5 & 8.8 \\
& & $100.2^{\mathrm{a}}$ \\
\hline
\end{tabular}

${ }^{2}$ Percentages may total more or less than 100 when rounded. 
Table 5 lists the mean and standard deviations for the Leadership Practices Inventory (IPI) self scores. For any one LPI factor, the maximum possible score was 30 . For the IPI total score, the maximum possible score was 150 . The "enabling others to act" was the highest scored factor and "inspiring a shared vision" was the lowest scored factor.

Table 6 presents the IPI scores for other. The "enabling others to act" was the highest scored factor and "inspiring a shared vision" was the lowest scored factor.

The Affective Communication Test (ACT) scores are presented in Table 7. The minimum score on the ACT was 13 and the maximum possible score on the $\underline{A C T}$ was 117. The $\underline{A C T}$ score for self was higher than the ACT score for other.

Table 8 lists the profitability data means and standard deviations for Return on Assets and Return on Equity. The means are percentages.

Table 9 presents the Erequencies and percentages on profitability data on Moody's Bond Rating. The largest percentage of corporations was listed in the "A" bond rating category.

Table 10 presents the frequencies and percentages on profitability data on S\&P Opinion. The largest percentage of corporations was given a "Three star" rating. 
TABLE 5

IEADERSHIP PRACTICES INVENTORY SCORES FOR SELF

Inventory Mean Standard Deviation

\begin{tabular}{lrr}
\hline LPI-SC & 23.5 & 2.470 \\
IPI-SI & 22.8 & 3.229 \\
LPI-SE & 25.6 & 2.390 \\
LPI-SM & 23.5 & 2.919 \\
IPI-SEH & 23.7 & 3.908 \\
LPI-S, TotaI & 119.0 & 10.483
\end{tabular}

NOTES. IPI-SC = Leadership Practices Inventory-Self, Challenging the Process; LPI-SI = Inspiring a Shared Vision; LPI-SE = Enabling Others to Act; LPI-SM = Modeling the way; LPI-SEH = Encouraging the Heart. 
TABLE 6

LEADERSHID PRACTICES INVENTORY SCORES FOR OTHER

Inventory Mean Standard Deviation

$\begin{array}{lrr}\text { IPI-OC } & 22.9 & 2.598 \\ \text { IPI-OI } & 21.9 & 3.367 \\ \text { LPI-OE } & 24.6 & 3.535 \\ \text { LPI-OM } & 22.7 & 2.880 \\ \text { IPI-OEH } & 23.2 & 3.615 \\ \text { LPI-O, Total } & 114.4 & 11.733\end{array}$

NOTES. IPI-OC = Leadership Practices Inventory-Other, Challenging the Process; IPI-OI = Inspiring a Shared Vision; LPI-OE = Enabling Others to Act; IPI-OM = Modeling the Way; LPI-OEH = Encouraging the Heart. 
TABLE 7

AFFECTIVE COMMUNICATION TEST SCORES FOR SELF AND OTHER

\begin{tabular}{lll}
\hline Inventory & Mean & Standard Deviation \\
\hline ACT-S & 74.6 & 20.600 \\
ACT-O & 70.5 & 16.912 \\
\hline
\end{tabular}

Note. ACT-S = Affective Communication Test for Self, ACT-O = Affective Communication Test for Other.

TABLE 8

ROA AND ROE PROFITABILITY DATA

\begin{tabular}{lrl}
\hline Profit Measure & Mean $(\%)$ & Standard Deviation \\
\hline ROA & 4.477 & 5.779 \\
ROE & 14.677 & 8.810 \\
\hline
\end{tabular}

Note. ROA = Return on Assets, ROE = Return on Equity. 
TABLE 9

MOODY'S CORPORATE BOND RATING PROFITABILITY DATA

Profit Measure

Grouping

E

$\%$

Moody's Corporate

Bond Rating

$\begin{array}{lrr}\text { Aaa }^{\mathrm{a}} & 2 & 3.5 \\ \mathrm{Aa} & 7 & 12.3 \\ \mathrm{~A} & 16 & 28.1 \\ \mathrm{Baa} & 10 & 17.5 \\ \mathrm{Ba} & 2 & 3.5 \\ \mathrm{~B} & 2 & 3.5 \\ \mathrm{Caa} & 1 & 1.8 \\ \mathrm{Ca} & 0 & 0 \\ \mathrm{C} & 0 & 0 \\ \text { Unavailable } & 17 & 29.8\end{array}$

Total

57

100.0

\begin{abstract}
${ }^{a} \mathrm{Aaa}$ is best quality bonds, Aaa is high quality bonds, A is favorable investment bonds, Baa is for medium grade obligations, Ba is for speculative element bonds, B is for bonds which are not desirable, Caa is for poor standing bonds, $\mathrm{Ca}$ is for highly speculative bonds, and $\mathrm{C}$ is lowest rated bonds.
\end{abstract}


TABLE 10

S\&P OPINION PROFITABILITY DATA

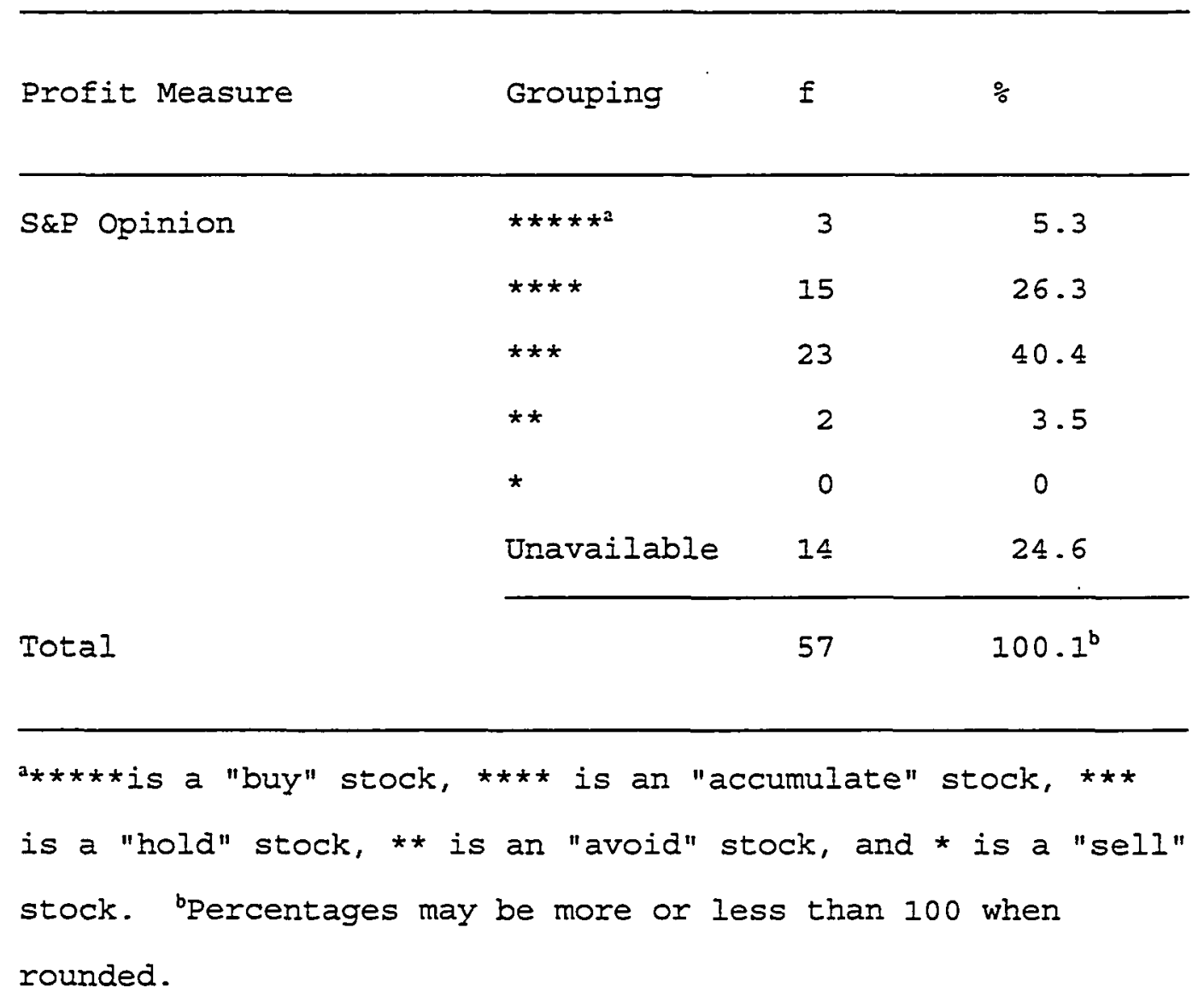


Table 11 presents the means of the sample compared to the remainder of the population for number of employees in the whole organization and for the current year's revenues. This comparison indicated no significant differences using a " $z$ " test for means at the .05 significance level.

Table 12 lists the Fortune 500 Corporations by industry category showing the number of corporations in the population and in the sample in each category. Of the 53 different categories of industries, 29 were represented in the sample for a percentage of 55 . There was only one industry category with more than 12 corporations that was not represented in the sample. That industry had 17 corporations.

TABLE 11

"Z" TEST FOR SAMPLE COMPARED TO POPULATION FOR NUMBER OF EMPLOYEES AND CURRENT REVENUE

Measure Sample

Remainder

$z$

sig

of Population

\begin{tabular}{|c|c|c|c|}
\hline $\begin{array}{l}\text { No. Employees } \\
\text { in Organization }\end{array}$ & 49,953 & 39,820 & 0.1691 \\
\hline $\begin{array}{l}\text { Current Revenue } \\
\text { (bililons of } \$ \text { ) }\end{array}$ & 11.90 & 8.49 & 0.2430 \\
\hline
\end{tabular}


TABLE 12

COMPARISON OF SAMPLE AND POPULATION BY INDUSTRY CATEGORY

\begin{tabular}{|c|c|c|}
\hline Industry & Population & Sample \\
\hline Aerospace & 9 & 2 \\
\hline Airlines & 8 & 2 \\
\hline AppareI & 3 & 0 \\
\hline Beverages & 4 & 0 \\
\hline Brokerage & 5 & 0 \\
\hline $\begin{array}{l}\text { Building Materials, } \\
\text { Glass }\end{array}$ & 5 & 1 \\
\hline Chemicals & 20 & 1 \\
\hline Commercial Banks & 31 & 5 \\
\hline $\begin{array}{l}\text { Computer \& Data } \\
\text { Service }\end{array}$ & 5 & 0 \\
\hline Computers, Office & 13 & 2 \\
\hline Diversified Financials & 12 & 0 \\
\hline $\begin{array}{l}\text { Electric \& Gas } \\
\text { Utilities }\end{array}$ & 35 & 6 \\
\hline $\begin{array}{l}\text { Electronics, Electrical } \\
\text { Equipment }\end{array}$ & 17 & 0 \\
\hline Engineering Construction & 7 & 1 \\
\hline Entertainment & 6 & 0 \\
\hline Food & 21 & 1 . \\
\hline Food \& Drug Stores & 23 & 4 \\
\hline Food Services & 4 & 1 \\
\hline
\end{tabular}


TABLE 12 (CONTINUED)

\begin{tabular}{|c|c|c|}
\hline Industry & Population & Sample \\
\hline $\begin{array}{l}\text { Forest \& Paper } \\
\text { Products }\end{array}$ & 19 & 1 \\
\hline General Merchandisers & 13 & 1 \\
\hline Health Care & 12 & 2 \\
\hline $\begin{array}{l}\text { Hotels, Casinos, } \\
\text { Resorts }\end{array}$ & 1 & 0 \\
\hline $\begin{array}{l}\text { Industrial \& Farm } \\
\text { Equipment }\end{array}$ & 12 & 1 \\
\hline Insurance, Stock & 23 & 3 \\
\hline Insurance, Mutual & 18 & 4 \\
\hline Marine Services & 1 & 0 \\
\hline Metal Products & 7 & 0 \\
\hline Metals & 8 & 1 \\
\hline $\begin{array}{l}\text { Mining, Crude OiI } \\
\text { Production }\end{array}$ & 1 & 0 \\
\hline $\begin{array}{l}\text { Motor Vehicles \& } \\
\text { Parts }\end{array}$ & 13 & 2 \\
\hline $\begin{array}{l}\text { Package \& Freight } \\
\text { Delivery }\end{array}$ & 3. & 0 \\
\hline Petroleum Refining & 19 & 1 \\
\hline Pharmaceuticals & 10 & 2 \\
\hline Pipelines & 5 & 0 \\
\hline Pubiishing, Printing & 7 & 1 \\
\hline Railroads & 7 & 1 \\
\hline Rubber \& Plastic & 2 & 0 \\
\hline
\end{tabular}


TABLE 12 (CONTINUED)

\begin{tabular}{|c|c|c|}
\hline Industry & Population & Sample \\
\hline Savings institutions & 2 & 1 \\
\hline $\begin{array}{l}\text { Scientific, Photographic } \\
\& \text { Control Equipment }\end{array}$ & 8 & 0 \\
\hline Soaps, Cosmetics & 4 & 2 \\
\hline Specialist Retailers & 20 & 2 \\
\hline Telecommunications & 15 & 4 \\
\hline Temporary Help & 3 & 1 \\
\hline Textiles & $I$ & 0 \\
\hline Toప̃acco & 3 & 0 \\
\hline Toys, Sporting Goods & 2 & 0 \\
\hline $\begin{array}{l}\text { Transportation } \\
\text { Equipment }\end{array}$ & 1 & 0 \\
\hline Truck Ieasing & 1 & 0 \\
\hline Trucking & 2 & 0 \\
\hline Waste Management & 2 & 0 \\
\hline Wholesalers & 26 & 1 \\
\hline Miscellaneous & 1 & 0 \\
\hline Total Categories & 53 & 29 \\
\hline
\end{tabular}


Relationship between Leadership and Method of

\section{Training}

Hypothesis one stated that there is no significant relationship between leadership behaviors of leaders in training organizations and method of training. The Leadership Practices Inventory for self and other scores and the Affective Communication Test scores were compared to the number of newer training methods used using the Pearson product-moment correlation analysis. The spearman rho correlation data are given for comparison purposes. The data in Tables 13 through 15 indicate that there are no significant differences at the .0125 significance level. In addition to there not being any significant differences, none of the correlation coefficients is greater than .272 which would indicate only low relationships. All of the correlation coefficients for the $\mathrm{ACT}$ are negative which would indicate that the more charismatic training leaders would not use the newer training methods. The null hypothesis is retained.

Relationship between Leadership and Profitability Hypothesis two siated that there is no significant relationship between leadership behavior of leaders in training organizations and organization profitability. The Leadership Practices Inventory for self and other scores and the Affective Communications Test scores were compared to ROA, ROE, the Moody's Corporate Bond Rating, and the 
TABLE 13

CORRELATION OF LEADERSHIP PRACTICES INVENTORY-SELE TO NUMBER OF NEWER TRAINING METHODS

\begin{tabular}{|c|c|c|c|}
\hline \multirow[b]{2}{*}{ Inventory } & \multicolumn{3}{|c|}{ Number of Newer Training Methods } \\
\hline & $r$ & Sig & $\mathrm{N}$ \\
\hline \multirow[t]{2}{*}{ LPI-SC } & $.015^{\mathrm{a}}$ & .916 & 51 \\
\hline & $(-.020)^{b}$ & $(.892)$ & $(5 I)$ \\
\hline \multirow[t]{2}{*}{ LPI -SI } & -.025 & .862 & 51 \\
\hline & $(-.076)$ & $(.598)$ & (51) \\
\hline \multirow[t]{2}{*}{ IPI -SE } & .073 & .611 & 51 \\
\hline & $(.260)$ & $(.858)$ & $(5 I)$ \\
\hline \multirow[t]{2}{*}{ LPI-SM } & .247 & .080 & 51 \\
\hline & $(.210)$ & $(.140)$ & (5I) \\
\hline \multirow[t]{2}{*}{ LPI-SEH } & -.015 & .919 & 51 \\
\hline & $(-.045)$ & $(.754)$ & (5I) \\
\hline \multirow[t]{2}{*}{ LPI-S, Total } & .055 & .699 & $5 I$ \\
\hline & $(.019)$ & $(.896)$ & $(51)$ \\
\hline
\end{tabular}

NOTES. IPI-SC = Leadership Practices Inventory-Self, Challenging the Process; IPI-SI = Inspiring a Shared Vision; LPI-SE = Enabling Others to Act; LPI-SM = Modeling the Way; LPI-SEF = Encouraging the Heart.

'Pearson product-moment. 'spearman rho. 
TABLE 14

CORRELATION OF LEADERSHIP PRACTICES INVENTORY-OTHER TO

NUMBER OE NEWER TRAINING METHODS

\begin{tabular}{|c|c|c|c|}
\hline \multirow[b]{2}{*}{ Inventory } & \multicolumn{3}{|c|}{ Number of Newer Training Methods } \\
\hline & $r$ & Sig & $\mathbf{N}$ \\
\hline \multirow[t]{2}{*}{ IPI-OC } & $.233^{\mathrm{a}}$ & .099 & 51 \\
\hline & $(.272)^{b}$ & $(.051)$ & $(51)$ \\
\hline \multirow[t]{2}{*}{ LPI-OI } & .055 & .704 & 51 \\
\hline & $(.112)$ & $(.431)$ & $(51)$ \\
\hline \multirow[t]{2}{*}{ IPI-OE } & .037 & .795 & 51 \\
\hline & $(.055)$ & $(.701)$ & $(51)$ \\
\hline \multirow[t]{2}{*}{ IPI-OM } & .093 & .516 & 51 \\
\hline & $(.129)$ & $(.362)$ & $(51)$ \\
\hline \multirow[t]{2}{*}{ LPI-OEF } & .015 & .915 & 51 \\
\hline & $(.056)$ & $(.696)$ & $(51)$ \\
\hline \multirow[t]{2}{*}{ LPI-0, Total } & .128 & .370 & 51 \\
\hline & $(.146)$ & $(.302)$ & (51) \\
\hline
\end{tabular}

NOTES. LPI-OC = Ieadership Practices Inventory-Other,

Challenging the Process; LPI-OI = Inspiring a Shared Vision;

LPI-OE = Enabling Others to Act; LPI-OM = Modeling the Way;

LPI-OEH = Encouraging the Heart.

${ }^{2}$ Pearson product-moment. 'spearman rho. 
TABIE 15

CORRELATION OF AFFECTIVE COMMUNICAITON TEST FOR SELF AND OTHER TO NUMBER OF NEWER TRAINING METHODS

\begin{tabular}{|c|c|c|c|}
\hline \multirow[b]{2}{*}{ Inventory } & \multicolumn{3}{|c|}{ Number of Newer Training Methods } \\
\hline & $r$ & Sig & $\mathrm{N}$ \\
\hline \multirow[t]{2}{*}{$A C T-S$} & $-.026^{2}$ & .859 & 51 \\
\hline & $(-.096)^{b}$ & $(.504)$ & (5I) \\
\hline \multirow[t]{2}{*}{$\mathrm{ACT}-\mathrm{O}$} & -.125 & .383 & 51 \\
\hline & $(-.095)$ & $(.501)$ & (5I) \\
\hline
\end{tabular}

Note. ACT-S = Affective Communication Test for Self, ACT-O

= Affective Communication Test for Other.

${ }^{2}$ Pearson product-moment. 'Spearman rho. 
Standard and Poor's Opinion using the Pearson product-moment correlation analysis. The spearman rho correlation data are given for comparison purposes. The data in Tables 16 through 25 indicate that there are no significant

differences at the .0125 significance level. In addition to there not being any significant differences, none of the correlation coefficients is greater than .399, with most being below .300 . These low coefficients would indicate low relationships. The null hypothesis is retained.

\section{Relationship between Method of Training and Profitability}

Hypothesis three stated that there is no significant relationship between method of training and organization profitability. The number of newer training methods used was compared to ROA, ROE, the Moody's Corporate Bond Rating, and the Standard and Poor's Opinion using the Pearson product-moment correlation analysis. The spearman rho correlation data are given for comparison purposes. The data in Table 28 indicate that the number of newer training methods is significantly correlated to ROA with a Pearson product-moment correlation coefficient of .363 . This value would indicate a low, positive relationship. There are no other significant differences at the .0125 significance level. The correlation coefficient for the Moody's Bond Rating was .330 , but this was not significant. Both the Pearson and Spearman correlation coefficients for 
TABLE 16

CORRELATION OF LEADERSHIP PRACTICES INVENTORY-SELF

TO RETURN ON ASSETS

\begin{tabular}{|c|c|c|c|}
\hline \multirow[b]{2}{*}{ Inventory } & \multicolumn{3}{|c|}{ Return on Assets } \\
\hline & $r$ & Sig & $\mathrm{N}$ \\
\hline \multirow[t]{2}{*}{ LPI-SC } & $-.015^{2}$ & .916 & 53 \\
\hline & $(-.036)^{b}$ & $(.799)$ & $(53)$ \\
\hline \multirow[t]{2}{*}{ LPI-SI } & -.088 & .533 & 53 \\
\hline & $(-.038)$ & $(.788)$ & $(53)$ \\
\hline \multirow[t]{2}{*}{ LPI-SE } & .030 & .833 & 53 \\
\hline & $(.067)$ & $(.630)$ & $(53)$ \\
\hline \multirow[t]{2}{*}{ LPI-SM } & .088 & .954 & 53 \\
\hline & $(.133)$ & $(.340)$ & (53) \\
\hline \multirow[t]{2}{*}{ LPI-SEH } & -.076 & .588 & 53 \\
\hline & $(-.014)$ & $(.919)$ & $(53)$ \\
\hline \multirow[t]{2}{*}{ LPI-S, Total } & -.060 & .668 & 53 \\
\hline & $(.035)$ & $(.806)$ & (53) \\
\hline
\end{tabular}

NOTES. LPI-SC = Leadership Practices Inventory-Self, Challenging the Process; LPI-SI = Inspiring a Shared Vision; LPI-SE = Enabling Others to ACt; LPI-SM = Modeling the Way; IPI-SEH = Encouraging the Heart.

${ }^{a}$ Pearson product-moment. 'spearman rho. 
TABLE 17

CORRELATION OF LEADERSHIP PRACTICES INVENTORY-OTHER

TO RETURN ON ASSETS

\begin{tabular}{|c|c|c|c|}
\hline \multirow[b]{2}{*}{ Inventory } & \multicolumn{3}{|c|}{ Return on Assets } \\
\hline & $r$ & Sig & $\mathrm{N}$ \\
\hline \multirow[t]{2}{*}{ LPI-OC } & $.300^{\mathrm{a}}$ & .024 & 57 \\
\hline & $(.274)^{b}$ & $(.039)$ & (57) \\
\hline \multirow[t]{2}{*}{ LPI-OI } & .028 & .837 & 57 \\
\hline & $(.095)$ & $(.712)$ & $(57)$ \\
\hline \multirow[t]{2}{*}{ LPI-OE } & -.050 & .712 & 57 \\
\hline & $(-.041)$ & $(.762)$ & (57) \\
\hline \multirow[t]{2}{*}{ LPI-OM } & .087 & .521 & 57 \\
\hline & $(.152)$ & $(.259)$ & $(57)$ \\
\hline \multirow[t]{2}{*}{$L P I-O E H$} & .057 & .672 & 57 \\
\hline & $(.082)$ & $(.543)$ & (57) \\
\hline \multirow[t]{2}{*}{ LPI-O, Total } & .131 & .333 & 57 \\
\hline & $(.194)$ & $(.149)$ & $(57)$ \\
\hline
\end{tabular}

NOTES. LPI-OC = Leadership Practices Inventory-Other, Challenging the Process; IPI-OI = Inspiring a Shared Vision; LPI-OE = Enabling Others to ACt; LPI-OM = Modeling the Way; IPI-OEH = Encouraging the Heart.

aPearson product-moment. 'spearman rho. 
TABLE 18

CORRELATION OF AFEECTIVE COMMUNICATION TEST FOR

SELF AND OTHER TO RETURN ON ASSETS

\begin{tabular}{lccc}
\hline & Return on Assets & \\
\cline { 2 - 4 } Inventory & & Sig & $\mathrm{N}$ \\
& & & \\
\hline ACT-S & $.241^{2}$ & .085 & 52 \\
ACT-0 & $(.083)^{\mathrm{b}}$ & $(.556)$ & $(52)$ \\
& .276 & .038 & 57 \\
& $(.137)$ & $(.311)$ & $(57)$ \\
\hline
\end{tabular}

Note. ACT-S = Affective Communication Test for self, ACT-O

= Affective Communication Test for other.

${ }^{2}$ Pearson product-moment. 'Spearman rho. 
TABLE 19

CORRELATION OF LEADERSHIP PRACTICES INVENTORY-SELE

TO RETURN ON EOUITY

\begin{tabular}{|c|c|c|c|}
\hline \multirow[b]{2}{*}{ Inventory } & \multicolumn{3}{|c|}{ Return on Equity } \\
\hline & $r$ & Sig & $\mathrm{N}$ \\
\hline \multirow[t]{2}{*}{ LPI-SC } & $.241^{2}$ & .098 & 48 \\
\hline & $(.282)^{b}$ & $(.052)$ & $(48)$ \\
\hline \multirow[t]{2}{*}{ IPI-SI } & .076 & .609 & 48 \\
\hline & $(.045)$ & $(.760)$ & $(48)$ \\
\hline \multirow[t]{2}{*}{ LPI-SE } & .061 & .682 & 48 \\
\hline & $(.076)$ & $(.606)$ & $(48)$ \\
\hline \multirow[t]{2}{*}{ LPI-SM } & .067 & .648 & 48 \\
\hline & $(.059)$ & $(.696)$ & $(48)$ \\
\hline \multirow[t]{2}{*}{ LPI-SEH } & .087 & .557 & 48 \\
\hline & $(.092)$ & $(.536)$ & $(48)$ \\
\hline \multirow[t]{2}{*}{ LPI-S, Total } & .136 & .357 & 48 \\
\hline & $(.151)$ & $(.305)$ & $(48)$ \\
\hline
\end{tabular}

NOTES. LPI-SC = Leadership Practices Inventory-Self,

Challenging the Process; IPI-SI = Inspiring a Shared Vision; LPI-SE = Enabling Others to ACt; IPI-SM = Modeling the Way; LPI-SEH = Encouraging the Heart.

${ }^{2}$ Pearson product-moment. 'spearman rho. 
TABLE 20

CORRELATION OF LEADERSHIP PRACTICES INVENTORY-OTHER TO

RETURN ON EOUITY

\begin{tabular}{|c|c|c|c|}
\hline \multirow[b]{2}{*}{ Inventory } & \multicolumn{3}{|c|}{ Return on Equity } \\
\hline & $r$ & Sig & $\mathrm{N}$ \\
\hline \multirow[t]{2}{*}{ LPI-OC } & $.286^{2}$ & .040 & 52 \\
\hline & $(.243)^{b}$ & $(.083)$ & (52) \\
\hline \multirow[t]{2}{*}{ LPI-OI } & .056 & .694 & 52 \\
\hline & $(.045)$ & $(.749)$ & $(52)$ \\
\hline \multirow[t]{2}{*}{ IPI-OE } & .125 & .378 & 52 \\
\hline & $(.095)$ & $(.237)$ & $(52)$ \\
\hline \multirow[t]{2}{*}{ LPI-OM } & .167 & .237 & 52 \\
\hline & $(.128)$ & $(.366)$ & $(52)$ \\
\hline \multirow[t]{2}{*}{ LPI-OEH } & .210 & .126 & 52 \\
\hline & $(.122)$ & $(.390)$ & (52) \\
\hline \multirow[t]{2}{*}{ IPI-O, Total } & .280 & .044 & 52 \\
\hline & $(.262)$ & $(.061)$ & (52) \\
\hline
\end{tabular}

NOTES. IPI-OC = Leadership Practices Inventory-Other,

Challenging the Process; LPI-OI = Inspiring a Shared Vision;

IPI-OE = Enabling Others to Act; IPI-OM = Modeling the Way;

LPI-OEH = Encouraging the Heart.

${ }^{a}$ Pearson product-moment. 'bspearman rho. 
TABLE 21

CORRELATION OF AFFECTIVE COMMUNICATION TEST FOR SELF AND OTHER TO RETURN ON EQUITY

\begin{tabular}{lccc}
\hline & \multicolumn{2}{c}{ Return on Equity } \\
\cline { 2 - 4 } Inventory & \multicolumn{2}{c}{ Sig } & $\mathrm{N}$ \\
\hline ACT-S & $.065^{\mathrm{a}}$ & .666 & 47 \\
& $(.058)^{\mathrm{b}}$ & $(.697)$ & $(47)$ \\
ACT-O & .007 & .960 & 52 \\
& $(-.019)$ & $(.894)$ & $(52)$ \\
\hline
\end{tabular}

Note. $A C T-S=$ Affective Communication Test for self, ACT-O

= Affective Communication Test for others.

${ }^{a}$ Pearson product-moment. 'spearman rho. 
TABLE 22

CORRELATION OF LEADERSHIP PRACTICES INVENTORY-SELF

TO MOODY'S BOND RATING

\begin{tabular}{|c|c|c|c|}
\hline \multirow[b]{2}{*}{ Inventory } & \multicolumn{3}{|c|}{ Moody's Bond Rating } \\
\hline & $\therefore r$ & Sig & $\mathrm{N}$ \\
\hline \multirow[t]{2}{*}{ LPI-SC } & $.308^{a}$ & .060 & 38 \\
\hline & $(.283)^{b}$ & $(.085)$ & $(38)$ \\
\hline \multirow[t]{2}{*}{ LPI-SI } & .166 & .320 & 38 \\
\hline & $(.147)$ & $(.379)$ & $(38)$ \\
\hline \multirow[t]{2}{*}{ LPI-SE } & .081 & .631 & 38 \\
\hline & $(.077)$ & $(.645)$ & $(38)$ \\
\hline \multirow[t]{2}{*}{ IPI-SM } & .073 & .644 & 38 \\
\hline & $(.107)$ & $(.522)$ & $(38)$ \\
\hline \multirow[t]{2}{*}{ LPI-SEH } & .008 & .963 & 38 \\
\hline & $(-.049)$ & $(.770)$ & $(38)$ \\
\hline \multirow[t]{2}{*}{ IPI-S, Total } & .138 & .409 & 38 \\
\hline & $(.177)$ & $(.484)$ & $(38)$ \\
\hline
\end{tabular}

NOTES. LPI-SC = Leadership Practices Inventory-Self,

Challenging the Process; LPI-SI = Inspiring a Shared Vision;

IPI-SE = Enabling others to Act; LPI-SM = Modeling the Way;

LPI-SEH = Encouraging the Heart.

apearson product-moment.: 'spearman rho. 
Table 23

CORRELATION OF LEADERSHIP PRACTICES INVENTORY-OTHER TO

MOODY'S BOND RATING

\begin{tabular}{|c|c|c|c|}
\hline \multirow[b]{2}{*}{ Inventory } & \multicolumn{3}{|c|}{ Moody's Bond Rating } \\
\hline & $r$ & sig & $\mathbf{N}$ \\
\hline \multirow[t]{2}{*}{ IPI-OC } & $.319^{\mathrm{a}}$ & .045 & 40 \\
\hline & $(.307)^{b}$ & $(.054)$ & $(40)$ \\
\hline \multirow[t]{2}{*}{ IPI-OI } & .054 & .743 & 40 \\
\hline & $(.096)$ & $(.553)$ & $(40)$ \\
\hline \multirow[t]{2}{*}{ IPI-OE } & .166 & .304 & 40 \\
\hline & $(.215)$ & $(.183)$ & $(40)$ \\
\hline \multirow[t]{2}{*}{ LPI-OM } & .147 & .367 & 40 \\
\hline & $(.080)$ & $(.624)$ & $(40)$ \\
\hline \multirow[t]{2}{*}{ IPI-OEH } & .178 & .271 & 40 \\
\hline & $(.154)$ & $(.342)$ & $(40)$ \\
\hline \multirow[t]{2}{*}{ IPI-O, Total } & .240 & .135 & 40 \\
\hline & $(.150)$ & $(.356)$ & $(40)$ \\
\hline
\end{tabular}

NOTES. LPI-OC = Leadership Practices Inventory-Other, Challenging the Process; IPI-OI = Inspiring a Shared Vision; IPI-OE = Enabling Others to Act; LPI-OM = Modeling the Way; LPI-OEH = Encouraging the Heart.

apearson product-moment. 'spearman rho. 
TABLE 24

CORRELATION OF AFEECTIVE COMMUNICAITON TEST FOR SELF

AND OTHER TO MOODY'S BOND RATING




TABLE 25

CORRELATION OF LEADERSHIP PRACTICES INVENTORY-SELE

TO S\&P OPINION

\begin{tabular}{|c|c|c|c|}
\hline \multirow[b]{2}{*}{ Inventory } & \multicolumn{3}{|c|}{ S\&P Opinion } \\
\hline & $r$ & Sig & $\mathrm{N}$ \\
\hline \multirow[t]{2}{*}{ LPI-SC } & $.060^{2}$ & .711 & 41 \\
\hline & $(.035)^{b}$ & $(.828)$ & $(4 I)$ \\
\hline \multirow[t]{2}{*}{ LPI-SI } & .296 & .060 & 41 \\
\hline & $(.272)$ & $(.085)$ & $(41)$ \\
\hline \multirow[t]{2}{*}{ LPI-SE } & -.100 & .532 & 41 \\
\hline & $(-.058)$ & $(.720)$ & $(41)$ \\
\hline \multirow[t]{2}{*}{ IPI-SM } & .159 & .320 & 41 \\
\hline & $(.138)$ & $(.390)$ & (4I) \\
\hline \multirow[t]{2}{*}{ LPI-SEH } & -.366 & .018 & 41 \\
\hline & $(.399)$ & $(.010)$ & (4I) \\
\hline \multirow[t]{2}{*}{ LPI-S, Total } & .000 & 1.000 & 41 \\
\hline & $(-.002)$ & $(.990)$ & $(\Delta I)$ \\
\hline
\end{tabular}

NOTES. LPI-SC = Leadership Practices Inventory-Self, Challenging the Process; LPI-SI = Inspiring a Shared Vision; LPI-SE = Enabling Others to Act; LPI-SM = Modeling the Way; LPI-SEH = Encouraging the Heart.

${ }^{2}$ Pearson product-moment. 'bpearman rho. 
TABLE 26

CORRELATION OF LEADERSHIP PRACTICES INVENTORY-OTHER

TO S\&P OPINION

\begin{tabular}{|c|c|c|c|}
\hline \multirow[b]{2}{*}{ Inventory } & \multicolumn{3}{|c|}{ S\&P Opinion } \\
\hline & $r$ & Sig & $\mathrm{N}$ \\
\hline \multirow[t]{2}{*}{ LPI-OC } & $.348^{2}$ & .022 & 43 \\
\hline & $(.325)^{b}$ & $(.034)$ & $(43)$ \\
\hline \multirow[t]{2}{*}{ LPI-OI } & .206 & .186 & 43 \\
\hline & $(.236)$ & $(.128)$ & $(43)$ \\
\hline \multirow[t]{2}{*}{ LPI-OE } & -.174 & .264 & 43 \\
\hline & $(.027)$ & $(.861)$ & (43) \\
\hline \multirow[t]{2}{*}{ IPI-OM } & .166 & .289 & 43 \\
\hline & $(.213)$ & $(.170)$ & $(43)$ \\
\hline \multirow[t]{2}{*}{ LPI-OEF } & -.041 & .792 & 43 \\
\hline & $(.024)$ & $(.877)$ & $(43)$ \\
\hline \multirow[t]{2}{*}{ LPI-O, Total } & .134 & .393 & 43 \\
\hline & $(.238)$ & $(.124)$ & (43) \\
\hline
\end{tabular}

NOTES. LPI-OC = Leadership Practices Inventory-Other, Challenging the Process; IPI-OI = Inspiring a Shared Vision; LPI-OE = Enabling Others to Act; LPI-OM = Modeling the Way; LPI-OEH = Encouraging the Heart.

aPearson product-moment. 'bspearman rho. 
TABLE 27

CORRELATION OF AFEECTIVE COMMUNICAITON TEST FOR

SELE AND OTHER TO S\&P OPINION

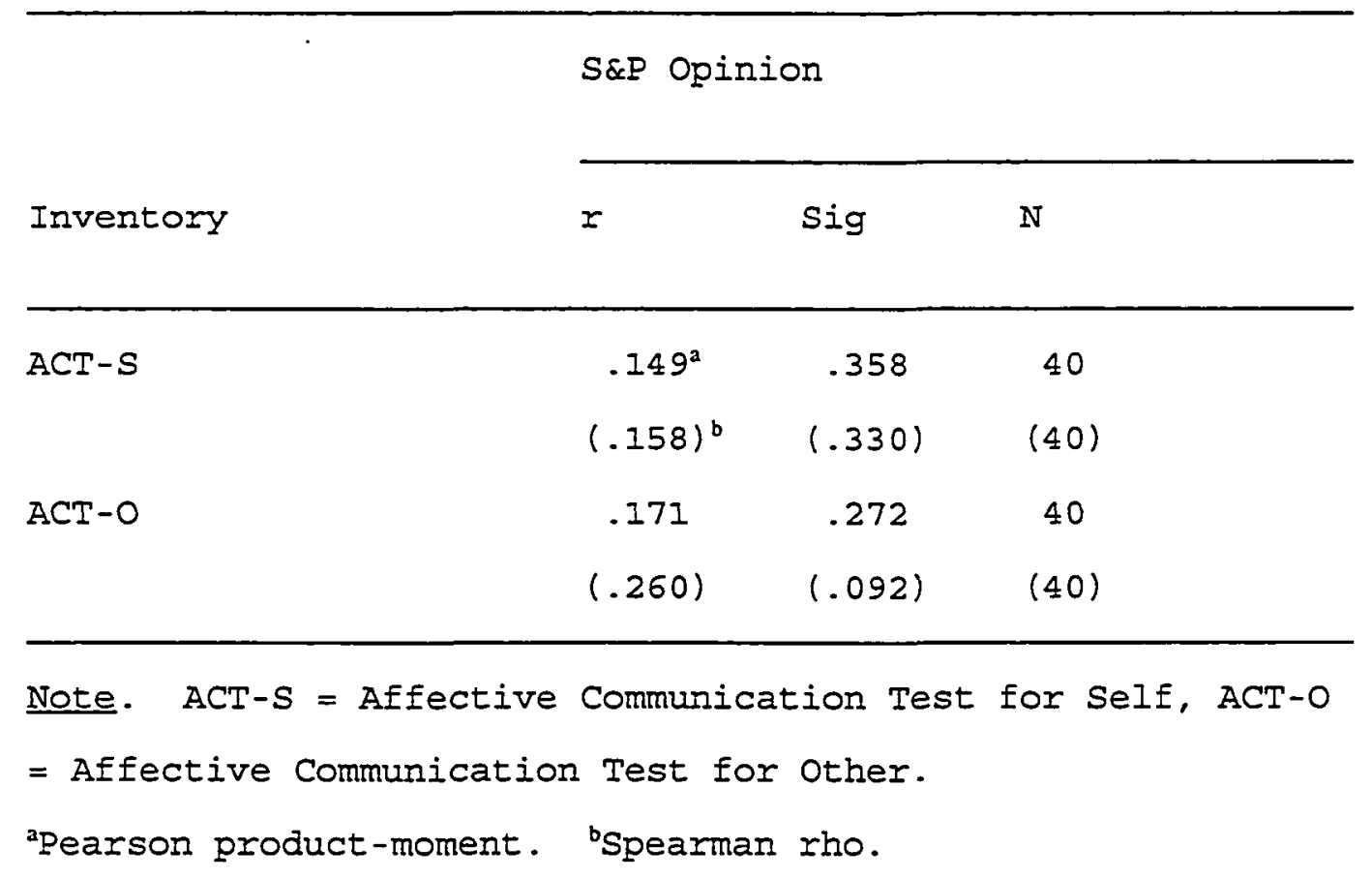


TABLE 28

COMPARISON OE NUMBER OF NEWER TRAINING METHODS

TO ROA, ROE, MOODY'S BOND RATING, AND SEP OPINION

$$
\text { Number of Newer Training Methods }
$$

\begin{tabular}{lccc} 
Profit Measure & \multicolumn{1}{l}{ Sig } & $\mathrm{N}$ \\
\hline Return on Assets & $.363^{3}$ & $.008^{*}$ & 47 \\
& $(.381)^{\mathrm{b}}$ & $(.005)$ & $(47)$ \\
Return on Equity & .195 & .118 & 47 \\
Moody's Bond Rating & $(.205)$ & $(.167)$ & $(47)$ \\
& $(.330$ & .049 & 21 \\
S\&P Opinion & -.020 & .902 & 39 \\
& $(-.020)$ & $(.904)$ & $(39)$ \\
\hline
\end{tabular}

${ }^{a}$ Pearson product-moment. 'spearman rho.

$\underline{p}<.0125$ 
the S\&P Opinion are negative, but these are not significant. The null hypothesis was rejected.

\section{Relationship between Demographics and Profitability}

Hypothesis four stated that there is no significant relationship between demographic data such as: age, gender, race, education level, number of employees in the training department, and number of years in current position. The demographics were compared to organization profitability using the Pearson product-moment correlation analysis. The Spearman rho correlation data are given for comparison purposes. The data in Tables 29 through 32 indicate that there are no significant differences at the .0125 significance level. In addition to there not being any significant differences, none of the correlation coefficients for age, gender, race, education level, or number of years in the current position are greater than .341 which would indicate only low relationships. Most of these coefficients are below .300 or negative. The only moderate correlation coefficient is the spearman value for number of employees in the training organization with Moody's Bond Rating which is .441; however, the Pearson value is only .196. The null hypothesis is retained. 
TABLE 29

CORRELATION OF AGE, GENDER, EDUCATION IEVEL, NO. OF

EMPLOYEES IN TRAINING ORGANIZATION, AND NO. OF YEARS IN

CURRENT POSITION TO RETURN ON ASSETS

\begin{tabular}{|c|c|c|c|}
\hline \multirow[b]{2}{*}{ Demographic } & \multicolumn{3}{|c|}{ Return on Assets } \\
\hline & $r$ & Sig & $\mathbf{N}$ \\
\hline \multirow[t]{2}{*}{ Age } & $.307^{\mathrm{a}}$ & .030 & 50 \\
\hline & $(.341)^{b}$ & $(.015)$ & $(50)$ \\
\hline \multirow[t]{2}{*}{ Gender } & .104 & .443 & 57 \\
\hline & $(.062)$ & $(.646)$ & (57) \\
\hline \multirow[t]{2}{*}{ Race } & -.148 & .301 & 51 \\
\hline & $(-.304)$ & $(.030)$ & (51) \\
\hline \multirow{2}{*}{$\begin{array}{l}\text { Education } \\
\text { Level }\end{array}$} & .019 & .897 & 50 \\
\hline & $(-.067)$ & $(.644)$ & $(50)$ \\
\hline $\begin{array}{l}\text { No. of } \\
\text { Employees in }\end{array}$ & & .907 & 50 \\
\hline $\begin{array}{l}\text { Training } \\
\text { Organization }\end{array}$ & $(.077)$ & $(.594)$ & $(50)$ \\
\hline $\begin{array}{l}\text { No. of Years } \\
\text { in Current }\end{array}$ & .059 & .682 & 50 \\
\hline Position & $(.139)$ & $(.335)$ & $(50)$ \\
\hline
\end{tabular}

aPearson product-moment. 'bpearman rho. 
TABLE 30

CORRELATION OF AGE, GENDER, EDUCATION LEVEL, NO. OF

EMPLOYEES IN TRAINING ORGANIZATION, AND NO. OF YEARS IN

CURRENT POSITION TO RETURN ON EOUITY

\begin{tabular}{|c|c|c|c|}
\hline \multirow[b]{2}{*}{ Demographic } & \multicolumn{3}{|c|}{ Return on Equity } \\
\hline & $r$ & Sig & $\mathrm{N}$ \\
\hline \multirow[t]{2}{*}{ Age } & $.298^{\mathrm{a}}$ & .046 & 45 \\
\hline & $(.313)^{b}$ & $(.036)$ & $(45)$ \\
\hline \multirow[t]{2}{*}{ Gender } & -.042 & .766 & 52 \\
\hline & $(.009)$ & $(.946)$ & $(52)$ \\
\hline \multirow[t]{2}{*}{ Race } & -.109 & .473 & 45 \\
\hline & $(-.216)$ & $(.149)$ & $(45)$ \\
\hline \multirow{2}{*}{$\begin{array}{l}\text { Education } \\
\text { Level }\end{array}$} & -.103 & .503 & 45 \\
\hline & $(-.113)$ & $(.458)$ & $(45)$ \\
\hline $\begin{array}{l}\text { No. of } \\
\text { Employees in }\end{array}$ & .112 & .465 & 45 \\
\hline $\begin{array}{l}\text { Training } \\
\text { Organization }\end{array}$ & $(.164)$ & $(.281)$ & $(45)$ \\
\hline \multirow{2}{*}{$\begin{array}{l}\text { No of Years } \\
\text { in Current } \\
\text { Position }\end{array}$} & -.036 & .815 & 45 \\
\hline & $(-.026)$ & $(.867)$ & $(45)$ \\
\hline
\end{tabular}

${ }^{2}$ Pearson product-moment. 'bspearman rho. 
TABLE 31

CORRELATION OF AGE, GENDER, EDUCATION LEVEL, NO. OF

EMPLOYEES IN TRAINING ORGANIZAITON, AND NO. OF YEARS IN

CURRENT PUSITION TO MOODY'S BOND RATING

\begin{tabular}{|c|c|c|c|}
\hline \multirow[b]{2}{*}{ Demographic } & \multicolumn{3}{|c|}{ Moody's Bond Rating } \\
\hline & $r$ & Sig & $\mathrm{N}$ \\
\hline \multirow[t]{2}{*}{ Age } & $.020^{\mathrm{a}}$ & .908 & 35 \\
\hline & $(.035)^{b}$ & $(.843)$ & (35) \\
\hline \multirow[t]{2}{*}{ Gender } & .091 & .575 & 40 \\
\hline & $(.044)$ & $(.785)$ & $(40)$ \\
\hline \multirow[t]{2}{*}{ Race } & .101 & .557 & 35 \\
\hline & $(.105)$ & $(.541)$ & (35) \\
\hline \multirow{2}{*}{$\begin{array}{l}\text { Education } \\
\text { Level }\end{array}$} & -.308 & .071 & 35 \\
\hline & $(-.242)$ & $(.162)$ & (35) \\
\hline $\begin{array}{l}\text { No. of } \\
\text { Employees in }\end{array}$ & .196 & .259 & 35 \\
\hline $\begin{array}{l}\text { Training } \\
\text { Organization }\end{array}$ & $(.44 I)$ & $(.008)$ & (35) \\
\hline $\begin{array}{l}\text { No. of Years } \\
\text { in Current }\end{array}$ & & & \\
\hline Position & $(-.146)$ & $(.404)$ & (35) \\
\hline
\end{tabular}

${ }^{a}$ Pearson product-moment. 'bpearman rho. 
TABLE 32

CORRELATION OF AGE, GENDER, EDUCATION LEVEL, NO. OF

EMPLOYEES IN TRAINING ORGANIZATION, AND NO. OF YEARS IN

CURRENT POSITION TO S\&P OPINION

\begin{tabular}{|c|c|c|c|}
\hline \multirow[b]{2}{*}{ Demographic } & \multicolumn{3}{|c|}{ S\&P Opinion } \\
\hline & $r$ & Sig & $\mathbf{N}$ \\
\hline \multirow[t]{2}{*}{ Age } & $-.101^{\mathrm{a}}$ & .547 & 38 \\
\hline & $(-.083)^{b}$ & $(.619)$ & (38) \\
\hline \multirow[t]{2}{*}{ Gender } & .098 & .534 & 43 \\
\hline & $(.080)$ & $(.614)$ & $(43)$ \\
\hline \multirow[t]{2}{*}{ Race } & -.081 & .624 & 38 \\
\hline & $(.000)$ & $(1.000)$ & (38) \\
\hline \multirow{2}{*}{$\begin{array}{l}\text { Education } \\
\text { Level }\end{array}$} & -.004 & .981 & 38 \\
\hline & $(.016)$ & $(.926)$ & (38) \\
\hline $\begin{array}{l}\text { No. of } \\
\text { Employees in }\end{array}$ & .001 & .993 & 38 \\
\hline $\begin{array}{l}\text { Training } \\
\text { Organization }\end{array}$ & $(-.177)$ & $(.289)$ & (38) \\
\hline $\begin{array}{l}\text { No of Years } \\
\text { in Current }\end{array}$ & -.194 & .243 & 38 \\
\hline Position & $(-.133)$ & $(.427)$ & (38) \\
\hline
\end{tabular}

${ }^{a}$ Pearson product-moment. 'spearman rho. 


\section{Regression Analysis on ROA}

A regression analysis was performed using the two total values of the LPI scores, the $\mathrm{ACT}$ scores, and the number of newer training methods to predict profitability using ROA only as the dependent variable. The data in Table 33 indicate that the number of newer training methods in conjunction with the other factors can account for approximately $26 \%$ of the variation in ROA. Although none of the other "B" values are significant, this analysis shows the effect of the number of newer training methods on ROA.

\section{Summary}

Chapter 4 described the results and the analysis of the data. Responses were received from 57 of the 486 Fortune 500 corporations surveyed. A significant correlation was shown for the number of newer training methods compared to ROA. The number of newer training methods was also significant for regression on ROA. No other significant differences were observed.

Chapter 5 will present the findings, conclusions, and recommendations. 
TABLE 33

REGRESSION ANALYSIS OF LEADERSHIP PRACTICES INVENTORY TOTALS, AFEECTIVE COMMUNICATION TEST, AND NUMBER OF NEWER METHODS OF TRAINING ON RETURN ON ASSETS

\begin{tabular}{|c|c|c|c|c|c|}
\hline Variable & $b$ & $S E b$ & Beta & $t$ & sig $t$ \\
\hline ACT Other & .106 & .079 & .320 & 1.341 & .187 \\
\hline $\begin{array}{l}\text { LPI Other, } \\
\text { Total }\end{array}$ & .023 & .067 & .049 & 0.350 & .728 \\
\hline $\begin{array}{l}\text { No. Newer } \\
\text { Training } \\
\text { Methods }\end{array}$ & 1.175 & .383 & .407 & 3.072 & $.004^{*}$ \\
\hline $\begin{array}{l}\text { LPI Self, } \\
\text { Total }\end{array}$ & -.047 & .078 & -.085 & -.612 & .544 \\
\hline ACT Self & .022 & .066 & .005 & -.743 & .461 \\
\hline \multicolumn{6}{|c|}{$\underline{\underline{r}}^{2}=.255, \underline{E}(5,45)=3.079^{* *}$} \\
\hline
\end{tabular}


CHAPTER 5

FINDINGS, CONCLUSIONS, AND RECOMMENDATIONS

\begin{abstract}
Introduction
Chapter 5 contains the findings, conclusions, and recommendations based on the results of this study. The purpose of this study was to determine the relationship among leadership behavior of training leaders, methods of training, and organization profitability. The problem was addressed through a survey determining newer methods of training used, the Leadership Practices Inventory (LPI), and the Affective Communication Test (ACT).
\end{abstract}

\title{
Findings
}

The following findings are presented from the analysis of the data:

1. The sample size was very small compared to the total population.

2. No significant relationships were shown between the training leaders' leadership behaviors and the number of newer training methods.

3. No significant relationships were shown between the training leaders' leadership behaviors and organization profitability. 
4. A significant relationship was shown between the number of newer training methods used and organization profitability as measured by return on assets.

5. No significant relationships were shown between demographic data and organization profitability.

\section{Discussion of Findings}

Sample

The sample was considered to be representative of the population even though it was small and was not a random sample. There were no significant differences in the total number of employees or in the current revenues between the sample and the population. Fifty-five percent of the industry categories were represented in the sample and all the major industry categories were represented.

The two main reasons for no responses were that personnel at corporations were busy and that corporations did not do surveys by policy. There were many more organizations that dia not respond. One reason for this may have been the tremendous restructuring and downsizing currently occurring in American industry. This downsizing gives even more reason for training organizations to prove their worth by some profitability or performance measure. Even though confidentiality was assured, some corporations may have been concerned about giving other corporations a competitive advantage by participating in the study. 
Another reason for the low response rate may have been the lengtr and complexity of the questionnaire. In addition, some leaders may have been reluctant to do a survey involving their subordinates. If a leader does not feel that he or she is doing a good job, the leader does not want to do a survey that would cause the subordinates to think about the leader's performance. Simply reading over a questionnaire about good leadership practices may cause the subordinates to compare their leader with those practices.

\section{Leadership and Method of Training}

There were no significant relationships found between the training leaders' leadership behaviors and the number of newer training methods. In general, the empowered, transformational, visionary, and charismatic leadership behaviors did not have any effect on the organizations' use of the newer training methods. Leaders with these behaviors did not use the newer methods. It might be that other factors, such as the size of the organization, the type of organization, the type of training needed, and the training budget, may have had a greater effect on the use of the newer methods than training leader leadership behavior.

\section{Leadership and Profitability}

There were no significant relationships found between the training leaders' Ieadership behavior and organization profitability. In general, the empowered, transformational, 
visionary, and charismatic leadership behaviors did not have any effect on organizations' profitability. Although not significant for the purposes of this research, the leadership practice, "challenging the process," did have low, positive relationships for return on assets, return on equity, Moody's Bond Rating, and the Standard and Poor's Opinion. Some of these relationships were significant at the .05 level. There are so many other factors, such as top leadership style, market conditions, industry type, and economic conditions, that the training leaders' influence may be very small. These findings are in agreement with the findings of Bullis (1992), Hannon (1992) and Esrael (1992), who found no relationship between leadership styles and profitability. These findings are in opposition to the findings of Ostrow (1992/1993), Langley (1992/1993), and Maglairi (1992/1993), who found positive relationships between leadership behavior and profitability. Method of

\section{Training and Profitability}

There was a significant relationship found between the number of newer training methods used and organization profitability as measured by return on assets. Return on assets is a long term measure. No other relationships were shown for return on equity, Moody's Corporate Bond Rating, or Standard and Poor's Opinion, which are all short term measures. No cause and effect can be assumed, but this finding does show that the more profitable corporations do 
use the newer methods of training. Whether profitability or the newer methods of training came first cannot be determined. This finding does support organizations using the newer methods of training that could lead to greater profitability. This finding was similar to Ostrow's (1992/1993) finding of a link between training and profitability. Mitchell (1993) concluded that training must affect the bottom Iine, or return on assets, and this finding supports that conclusion.

It may be that cutting back on training expenses or not investing in newer methods of training may positively affect short term performance such as return on equity, Moody's Bond Rating, and the Standard and Poor's Opinion. This same practice, however, may have a negative effect on Iong term performance. Training is usually considered a long term investment in the organization's human resource, the people. U. S. corporations are notorious for taking short-term measures, like downsizing, that positively affect the shortterm performance and the investment community's opinion, but may negatively affect the long-term performance as organizations can not compete as effectively.

The following were considered the newer methods: (a) accelerated learning, (b) case study methods, (c) computerbased training, (d) experiential exercises/games/simulations, (e) interactive video instruction, (f) multimedia, (g) non-computerized self- 
study, (h) problem-based learning, and (i) video teleconferencing.

\section{Demographics and Profitability}

There were no relationships expected between demographics and profitability and this finding confirms that expectation. One finding of interest was the large number of female training leaders. Human Resource organizations have been shown to be a good place for females to advance to higher positions. A number of the Human Resources Vice-Presidents contacted in the study were also female.

\section{Conclusions}

The study was designed to determine relationships among leadership behavior of training leaders, the number of newer training methods used, and organization profit. The following conclusions are drawn:

1. From the data found in this study, the empowered, visionary, transformational, charismatic leadership behavior of the training leader does not seem important as far as organization profitability is concerned. The only factor that seemed to have an effect on profitability is "challenging the process." It was thought that training leaders with these behaviors would influence other leaders in the organization to help the organization achieve greater profitability. There are so many other factors, such as top 
leadership style, market conditions, industry type, and economic conditions, that the training leaders' influence may be very small.

2. From the data found in this study, the empowered, visionary, transformational, charismatic leadership behavior of the training leader is not important as far as the number of newer training methods used is concerned. It was thought that the training leaders with these behaviors would use the newer training methods in their organizations. It might be that other factors, such as the size of the organization, the type of organization, the type of training needed, and the training budget, may have had a greater effect on the use of the newer methods than training leader leadership behavior.

3. The training department leader's age, gender, race, educational level, number of years in current position and the number of employees in the training organization are not important as far as organization profitability is concerned.

4. The number of newer training methods used does have a bearing on the long-term organization profitability as measured by return on assets, but not on short-term organization profitability as measured by return on equity, Moody's Bond Rating, or Standard and Poor's Opinion. Decreasing investment on training, such as not using newer, improved methods may positively affect short-term 
performance, but may negatively affect long-term performance.

\section{Recommendations}

The following recommendations are proposed:

1. A similar study should be conducted in a particular industry. By doing this, profitability data would be expected to be more similar than across the entire Fortune 500 Companies.

2. The study should be replicated with efforts to get a larger sample size. University letterhead paper should be used, and additional follow-up letters and additional follow-up telephone calls should be made. The study could also be done at a time when $U$. S. businesses are not in so much turmoil or confusion.

3. Further study should be made on the effect of the leadership factor, "challenging the process," on organization profitability.

4. A study should be made that looks at the effect of Human Resources Vice-Presidents' leadership style on organization profitability. This effect might show a closer relationship than with training leaders.

5. Training for leaders in industrial or educational settings should always incorporate the newer methods of training to improve organization performance. 
6. Companies, which always have limited resources, should put whatever resources needed to use the newer, improved methods of training to improve performance.

7. The use of the older methods of training or education, such as lecture, should be supplemented with an emphasis on the use of the newer methods that involve the use of technology and more learner involvement. 


\section{REFERENCES}

100

Reproduced with permission of the copyright owner. Further reproduction prohibited without permission. 


\section{References}

Adeyemi-Bello, T. (1993). Generic strategies, leader attributes, environmental uncertainty, and organizational performance. An empirical investigation of contingencies and configurational outcomes. (Doctoral dissertation, University of Arkansas, 1992). Dissertation Abstracts International, 53, 2883-A. Alliger, G. M., \& Janak, E. A. (1989). Kirkpatrick's levels of training criteria: Thirty years leter. Personnel Psychology, 42, 331-341.

Beilman, G. (1981). 20 management musts for HRD directors. In R. Zemke, L. Standke, \& P. Jones. (Ed.). Designing and delivering cost-effective training and measuring the results. Minneapolis: Lakewood.

Bennis, W. (1989). On becoming a leader. New York: AddisonWesley

Bolt, J. F. (1990). How executives learn: The move from glitz to guts. Training \& Development Journal, $44(5)$, $83-87$.

Bretz, R. D., \& Thompsett, R. E. (1992). Comparing traditional and integrative learning methods in organizational training programs. Journal of Applied Psychology, 77, 941-95I. 
Bridges, E. M. (1992). Problem based learning for

administrators. Eugene, OR: ERIC Clearinghouse on Ejucational Management, University of Oregon.

Bryman, A. (1992). Charisma and leadership in ordanizations. Newbury Park, CA: Sage.

Budd, M. I. (1987). Self-Instruction. In R. I. Craig (Ed.). Training \& development handbook: A guide to human resource development. New York: AMACOM.

Bullis, R. C. (1992). The impact of leader behavior on organizational performance. (Doctoral dissertation, Texas Tech University, 1992). Dissertation Abstracts International, 53, 1209-A.

Burns, J. M. (1978). Leadership. New York: Harper \& Row. Byham, w. (1988). Zapp! The lightning of empowerment. New York: Harmony Books.

Carnevale, A. P., Gainer, I. J., \& Meltzer, A. S. (1990). Workplace basics training manual. San Francisco: Jossey-Bass.

Cournoyer, R. (1991). Integrative learning speeds teamwork. Management Review, $80(12), 43-44$.

Covey, S. R. (1990). Principle-centered leadership. New York: Simon and Schuster. Craig, R, \& Bittel, I. (Ed.). (1967). Training and development handbook. New York: McGraw Hill. 
Cunningham, W. G., \& Gresso, D. W. (1993). Cultural

leadershio: The culture of excellence in education.

Boston: Allyn \& Bacon.

Daniels, A. C. (1989). Performance management: Improving

gualitv productivity through positive reinforcement.

Tucker, GA: Performance Management Publications.

DePree, M. (1992). Leadership jazz. New York: Currency-

Doubleday.

Designing a value-added HR organization. (December 20 , 1993). What's Ahead in Human Resources. p. 2 .

Dixon, N. M. (1989). Self-defeating strategies of training departments. Performance \& Instruction, 28 (7), 23-26.

Doyle, J. (1991). Innovations in training. Credit Magazine, $17(1), 10-14$.

Drucker, P. F. (1954). The practice of management. New York: Harper \& Row.

Esrael, W. C. (1992). A study of credit union leadership styles and organizational performance. (Doctoral dissertation, Peabody College for Vanderbilt University, 1991). Dissertation Abstracts International, $53(1), 215-\mathrm{A}$. Eitington, J. E. (1984). The winning trainer, Houston: Gulf.

Fitzgerald, W. K. (1993) Training to become a business partner. Human Resources Professional, $\underline{5}(4), 29-32$. 
Fitz-enz, J. (1994, July). Yes... You can weigh training's value. Training. pp. 54-58.

The Fortune 500. (1994). Fortune, 129(8), 220-239.

Friedman, H. S., Prince, L. M., Riggio, R. E., \& DiMatteo, M. R. (1980). Understanding and assessing nonverbal expressiveness: The affective communication test. Journal of Personality and Social Psychology, $39(2)$, $333-351$.

Froiland, P. (1983, December). Learning Unlimited. Northwest Orient, pp. 47-52.

Froiland, P. (1993). Who's getting trained? Training, $\underline{30}(10), 53-65$.

Gaveski, D. M. (1993). De-mystifying multimedia.

Communication World, $10(4), 27-32$.

Gay, I. R. (1987). Eaucational research: Competencies for analysis and application. ( $3 r d$ ed.). Columbus, $O H$ : Merrill.

Gayeski, D. (1993). Starting (or reinventing) a communication (training) department. Performance \& Instruction, 32(9), 35-38.

Gerber, B. (1994a). A clean break for education at IBM. Training, $31(2) .34-36$.

Gerber, B. (1994b). Re-engineering the training department. Training, $31(5), 27-34$.

Gill, M. J., \& Meier, D. (1989). Accelerated learning takes off. Training \& Development Journal, 43 (I), 63-65. 
Gordon, J. (1986, June). What they don't teach you about

being a training manger. Training, pp. 22-32.

Gordon, J. (1990). Where the training goes. Training, $\underline{27}(10), 51-69$.

Fannon, J. M. (1992). The association between human resource management reputation and corporate performance. (Doctoral dissertation, Cornell University, 1992). Dissertation Abstracts International, 52, 4389-A.

Hassett, J. (1992). Simplifying ROI. Training, 29(9), 53-57. Hersey, P., \& Blanchard, K. H. (1982). Management of organizational behavior: Utilizing human resources. Englewood Cliffs, NJ: Prentice-Fall.

Hitchcock, D. E. (1988, March). Building instructional games. Training, pp. 33-39.

Hoy, W. K., \& Miskel, C. G. (1991). Educational administration: Theory, research, and practice. New York: McGraw-Hill.

Jasaitis, E. J. (1992). The written Neely Gardner. Public Administration Quarterly, $15(4), 422-440$.

Kotter. J. (1990). A force for change: How leadership differs from management. New York: Free Press. Kouzes, J. M., \& Posner, B. Z. (1987). The leadership challenge. San Francisco: Jossey-Bass. Kouzes, J. M., \& Posner, B. Z. (1988). Leadership practices inventory (LPI): Trainer's manual. San Diego, CA: University Associates. 
Kouzes, J. M., \& Posner, B. Z. (1992). Psychometric properties of the leadership practices inventory. San Diego, CA: Pfeiffer.

Langley, T. C. (1993). Concepts and styles of leadership as factors in the performance of the property/casualty insurance industry. (Doctoral dissertation, Golden Gate University, 1992). Dissertation Abstracts International, 54, 1009-A.

Lee, C. (1992). The budget blahs. Training, 29(10), 31-38. Longman, S. (1988). Building a training department from scratch. Training and Development Journal, $42(5), 44-$ 47.

Magliari, R. C. (1993). The influence of management style on small commercial bank success. (Doctoral dissertation, Webster University, 1992). Dissertation Abstracts International, 54, 243-A.

Malcolm, S. E. (1992). Re-engineering corporate training. Training, 29(8), 57-61.

McDougall, M. F. (1993). Innovative trainers and bureaucracies: An effective combination? Leadership \& Organizational Journal, 14(2), i-iii.

Meister, J. C. (1994). Corporate quality universities. Burr Ridge, IL: Irwin Professional Publishing. Mitchell, G. (1993). The trainer's handbook: The AMA guide to effective training (2nd ed.). New York: AMACOM. 
Montebello, A. R, \& Haga, M. (1994, January). To justify training, test, test again. Personnel Journal, pp. 8387.

Moody's Investor's Services. (1995). Moody's Industrial Manual (Vol 1). New York: Author. Nilson, C. (1991). Training for non-trainers: A do-ityourself guide for manacers. New York: AMACOM. Ostrow, M. H. (1993). The relationships among competitive strategy, human resource management practices and financial performance. (Doctoral dissertation, University of Maryland College Park, 1992). Dissertation Abstracts International, 54, 245-A. Pauchant, T. C. (1991). Transferential leadership: Towards a more complex understanding of charisma in organizations. Organization studies, 12(4), 507-527. Pearson, L. (1993, November). Is CD-ROM about to bloom?

Presentation Technologies, pp. 5-8. Peters, T. (1987). Thriving on chaos. New York: Harper and Row.

Petrini, C. M. (1990). Over the river and through the woods. Iraining \& Development Journal, $44(5), 25-36$. Pigors, P., \& Pigors, F. (1987). Case method. In R. I. Craig (Ed.). Training \& development handbook: A quide to human resource development. New York: McGraw-Hill. Pine, J., \& Tingley, J. C. (February, 1993). ROI of softskills training. Training. pp. 55-60. 
Pittman, J. I. (1987). Organization and management of the training function. In R. Zemke, I. Standke, \& P. Jones. (Ed.). Designing and delivering cost-effective training and measuring the results. Minneapolis: Lakewood.

Rachman, D. I., ì Mescom, M. H. (1987). Business today

(5th ed.). New York: Random House.

Richards, D. (1989, March). Self instructional text. Paper presented at the NSPI National Conference, Denver, CO. Richardson, R. J., \& Thayer, S. K. (1993). The charisma factor. Englewood Cliffs, NJ: Sage.

Schaff, D. (1981). Teleconferencing: It may change the way you train. In R. Zemke, I. Standke, \& P. Jones. (Ed.). Designing and delivering cost-effective training and measuring the results. Minneapolis: Lakewood.

Senge, P. (1990). The fifth discipline. New York:

Doubleday.

Sloman, M. (1994). coming in from the cold: A new role for trainers. Personnel Management, 26 (I), 24-27.

Solomon, C. M. (1993, June). Simulation training builds teams through experience. Personnel Journal, pp. 100108.

Spitz, C. (1992). Multimedia training at Hewlett-Packard. Training \& Development, $46(6), 39-41$.

Staff. (1991, June). Lessons learned starting a function have a long shelf life. Training Directors' Forum Newsletter, $I(6), 6$. 
Staff. (1991, August). Striving for perfection? These trainers have some ideas. Training Directors' Forum, $\underline{7}(8), 1-3$

Staff. (1991, December). 10 important lessons for developing skilled instructors. Training Directors' Forum Newsletter, $7(12), 1-4$.

Staff. (1994). 1994 industry report. Training. 31(10). 2974 .

Standard \& Poor's. (1995). Standard \& Poor's Stock Reports Index. New York: McGraw-Hill.

Stoner, J. A. F., \& Wankel, C. (1986). Management.

Englewood Cliffs, NJ: Prentice-Hall.

Thompson, B. I. (1991). Training in the great outdoors.

Training, $\underline{28}(5), 46-52$.

Thompson, V. H. (1994). Multimedia: The choice of a Swiss

bank. Training, 3I(I), 14-17.

Webster's third new international dictionary of the English language. (1966). Chicago: G \& C. Merriam Witkin, N. (1992). Success strategies for the training manager of the nineties. Performance \& Instruction.. $\underline{31}(4), 19-21$.

Zemke, R. (1981). Training here means listening and thinking. In R. Zemke, L. Standke, \& P. Jones. (Ed.). Designing and delivering cost-effective training and measuring the results. Minneapolis: Lakewood. 
APPENDICES

110

Reproduced with permission of the copyright owner. Further reproduction prohibited without permission. 
APPENDIX A

IETTER FOR PILOT STUDY

111

Reproduced with permission of the copyright owner. Further reproduction prohibited without permission. 
1244 Catawba Street

Kingsport, TN 37660-4506

(6I5) 247-1428 (home)

(615) 229-6691 (work)

May 20, 1995

Name

Title

Company

Street

City, State, zip

Dear $\mathrm{Mr} / \mathrm{Ms}$ :

I am enrolled in a doctoral program at ETSU and as a fellow ASTD member, I am asking for your help with my dissertation. I will be sending a survey instrument to other training leaders and part of that survey will be asking them to determine the types of training used in their companies' training departments. Would you please help me by reviewing the attached instrument and writing your comments and recommendations. I am particularly concerned that the training leaders understand the instrument and complete the instrument correctly. Your comments will be appreciated. Please returs the instrument with your comments in the selfaddressed, stamped envelope.

Sincerely,

Joseph D. Keith 
APPENDIX B

LETTER FOR HUMAN RESOURCES VICE-PRESIDENT

113

Reproduced with permission of the copyright owner. Further reproduction prohibited without permission. 
1244 Catawba street

Kingsport, TN 37660-4506

(615) 247-1428 (home)

(615) 229-6691 (work)

May 20, 1995

Name

Title

Company

street

City, State, Zip

Dear Mr/Ms:

I am enrolled in a doctoral program at East Tennessee state University, and I am asking for your help with my

dissertation. The study looks at the relationship among the leadership style of training leaders, the method of

training, and organization performance. I am trying to

answer the questions: Does leadership style affect

profitability? Does choice of training method affect

profitability? I am requesting a training leader in your

organization and five of his or her subordinates to fill out a survey on leadership behavior and charisma and mail these to me.

This survey should provide some valuable information about leadership and training. I will send a condensation of my study for publication in a training journal, but cannot guarantee publication. The completed dissertation will be available for loan from East Tennessee State University and also from UMI Dissertation Services.

If you would permit your organization to participate, I will guarantee confidentiality. No organization will be identified in the study. To participate, choose a training leader (training director or training manager of a training department or training division who has airect reports or subordinates) in your organization to participate. If you have more than one training leader, use the attached random number table to choose one at random. Random selection is very important to insure the statistical validity of the study. Please fill cut the enclosed post card with the name and address of the chosen training leader and your own name, and return the post card to me. The survey will take the training leader approximately 15 minutes to complete and will take each of the subordinates approximately 10 minutes to complete. I will provide anonymous feedback to the training leader on responses from the subordinates, if desired. This request is being sent to all Fortune 500 Companies that have been on the list for at least three years. 
Sincerely,

Joseph D. Keith

Reproduced with permission of the copyright owner. Further reproduction prohibited without permission. 


\section{APPENDIX C}

TABLE OF RANDOM NUMBERS 
TABLE OF RANDOM NUMBERS

\begin{tabular}{|c|c|c|c|c|c|c|c|c|c|c|c|c|c|c|c|c|c|c|c|c|c|c|c|c|c|c|c|}
\hline $\begin{array}{l}7 \\
5 \\
5 \\
5 \\
4\end{array}$ & $\begin{array}{ll}7 & 8 \\
5 & 9 \\
5 & 4 \\
5 & 1 \\
4 & 8\end{array}$ & $\begin{array}{l}0 \\
6 \\
3 \\
3 \\
5\end{array}$ & $\begin{array}{l}7 \\
7 \\
5 \\
8\end{array}$ & $\begin{array}{l}4 \\
4 \\
5 \\
3\end{array}$ & $\begin{array}{l}8 \\
5 \\
3 \\
3\end{array}$ & $\begin{array}{l}3 \\
6 \\
7 \\
6\end{array}$ & $\begin{array}{l}6 \\
9 \\
5 \\
7\end{array}$ & $\begin{array}{l}3 \\
4 \\
4 \\
4\end{array}$ & 5 & 4 & $\begin{array}{l}9 \\
6 \\
1 \\
0\end{array}$ & $\begin{array}{l}6 \\
6 \\
3 \\
3\end{array}$ & $\begin{array}{l}3 \\
3 \\
6 \\
7\end{array}$ & 5 & 9 & 2 & $\begin{array}{l}3 \\
5\end{array}$ & $\begin{array}{l}6 \\
2 \\
4 \\
6\end{array}$ & & 5 & $\begin{array}{l}5 \\
4\end{array}$ & $\begin{array}{l}2 \\
9 \\
6 \\
7\end{array}$ & $\begin{array}{l}0 \\
2 \\
3 \\
5\end{array}$ & 5 & $\begin{array}{l}5 \\
9 \\
6 \\
4\end{array}$ & & $\begin{array}{l}2 \\
5 \\
5\end{array}$ \\
\hline & $\begin{array}{ll}3 & 4 \\
6 & 6 \\
3 & 2 \\
0 & 2 \\
4 & 9\end{array}$ & $\begin{array}{l}7 \\
1 \\
3 \\
1 \\
2\end{array}$ & $\begin{array}{l}3 \\
2 \\
9 \\
2 \\
0\end{array}$ & $\begin{array}{l}4 \\
3 \\
4 \\
9 \\
2\end{array}$ & $\begin{array}{l}6 \\
2 \\
6 \\
2 \\
1\end{array}$ & $\begin{array}{l}3 \\
3 \\
4 \\
6 \\
5\end{array}$ & $\begin{array}{l}5 \\
8 \\
3 \\
8 \\
8\end{array}$ & $\begin{array}{l}4 \\
1 \\
5 \\
6 \\
6\end{array}$ & 8 & 6 & $\begin{array}{l}2 \\
5 \\
4\end{array}$ & 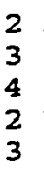 & $\begin{array}{l}2 \\
6 \\
5 \\
2 \\
6\end{array}$ & 0 & $\begin{array}{l}4 \\
5\end{array}$ & 7 & $\begin{array}{l}5 \\
5 \\
3\end{array}$ & $\begin{array}{l}0 \\
8\end{array}$ & & 2 & $\begin{array}{l}5 \\
3\end{array}$ & 4 & $\begin{array}{l}8 \\
5 \\
2 \\
9 \\
5\end{array}$ & $\begin{array}{l}4 \\
5 \\
6 \\
4 \\
2\end{array}$ & $\begin{array}{l}3 \\
4\end{array}$ & 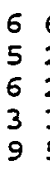 & 5 \\
\hline & $\begin{array}{ll}8 & 4 \\
5 & 6 \\
0 & 1 \\
5 & 2 \\
9 & 6\end{array}$ & $\begin{array}{l}9 \\
4 \\
5 \\
0 \\
6\end{array}$ & $\begin{array}{l}4 \\
2 \\
4 \\
6\end{array}$ & $\begin{array}{l}5 \\
4 \\
7 \\
6 \\
0\end{array}$ & $\begin{array}{l}1 \\
9 \\
3 \\
6 \\
6\end{array}$ & $\begin{array}{l}9 \\
4 \\
6 \\
4 \\
9\end{array}$ & $\begin{array}{l}4 \\
1 \\
I \\
9 \\
4\end{array}$ & $\begin{array}{l}1 \\
5 \\
3\end{array}$ & 2 & 6 & $\begin{array}{l}5 \\
4 \\
5 \\
3 \\
6\end{array}$ & 3 & $\begin{array}{l}3 \\
4 \\
2 \\
9 \\
6\end{array}$ & 7 & $\begin{array}{l}6 \\
3 \\
2 \\
3 \\
4\end{array}$ & $\begin{array}{l}7 \\
5\end{array}$ & 6 & 3 & & 6 & 1 & 6 & 6 & 7 & 3 & 7 & $\begin{array}{l}\frac{1}{1} \\
5\end{array}$ \\
\hline & $\begin{array}{ll}9 & 7 \\
2 & 2\end{array}$ & $\begin{array}{l}2 \\
2 \\
6 \\
8 \\
8\end{array}$ & $\begin{array}{l}1 \\
6 \\
4 \\
3\end{array}$ & $\begin{array}{l}3 \\
2 \\
1 \\
5 \\
5\end{array}$ & $\begin{array}{l}0 \\
9 \\
2 \\
6 \\
5\end{array}$ & $\begin{array}{l}4 \\
4 \\
4 \\
5 \\
9\end{array}$ & $\begin{array}{l}2 \\
9 \\
2 \\
6 \\
4\end{array}$ & $\begin{array}{l}6 \\
3 \\
5 \\
0 \\
7\end{array}$ & $\begin{array}{l}0 \\
1 \\
2 \\
6\end{array}$ & $\begin{array}{l}8 \\
6\end{array}$ & $\begin{array}{l}5 \\
2 \\
4 \\
3 \\
6\end{array}$ & $\begin{array}{l}2 \\
1\end{array}$ & $\begin{array}{l}4 \\
1 \\
5 \\
2 \\
4\end{array}$ & 2 & $\begin{array}{l}5 \\
8 \\
1 \\
4 \\
6\end{array}$ & $\begin{array}{l}9 \\
8\end{array}$ & $\begin{array}{l}3 \\
5 \\
4 \\
4 \\
7\end{array}$ & 6 & & 4 & 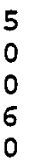 & 2 & 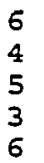 & 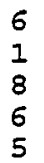 & 3 & 2 & $\begin{array}{l}8 \\
8 \\
3\end{array}$ \\
\hline & $\begin{array}{ll}5 & 2 \\
5 & 8\end{array}$ & $\begin{array}{l}5 \\
6 \\
0 \\
9 \\
6\end{array}$ & $\begin{array}{l}1 \\
4 \\
3 \\
9\end{array}$ & $\begin{array}{l}4 \\
5 \\
0 \\
9 \\
4\end{array}$ & $\begin{array}{l}7 \\
3 \\
6 \\
3 \\
8\end{array}$ & $\begin{array}{l}5 \\
9 \\
5 \\
1 \\
5\end{array}$ & $\begin{array}{l}3 \\
4 \\
3 \\
5 \\
7\end{array}$ & $\begin{array}{l}6 \\
8 \\
9 \\
3\end{array}$ & $\begin{array}{l}3 \\
4 \\
4\end{array}$ & 6 & $\begin{array}{l}5 \\
4 \\
4 \\
2 \\
9\end{array}$ & $\begin{array}{l}2 \\
3\end{array}$ & $\begin{array}{l}9 \\
4 \\
5 \\
2 \\
5\end{array}$ & $\begin{array}{l}6 \\
5\end{array}$ & $\begin{array}{l}8 \\
2 \\
1 \\
1\end{array}$ & $\begin{array}{l}3 \\
4\end{array}$ & $\begin{array}{l}6 \\
4 \\
5 \\
2 \\
3\end{array}$ & $\begin{array}{l}8 \\
6 \\
7\end{array}$ & & 6 & 0 & $\begin{array}{l}9 \\
2\end{array}$ & $\begin{array}{l}3 \\
6 \\
5 \\
2 \\
7\end{array}$ & $\begin{array}{l}1 \\
6 \\
7 \\
6 \\
1\end{array}$ & $\begin{array}{l}3 \\
2 \\
3 \\
9\end{array}$ & $\begin{array}{l}8 \\
2 \\
3\end{array}$ & $\begin{array}{l}8 \\
5 \\
7 \\
4\end{array}$ \\
\hline & 35 & $\begin{array}{l}4 \\
6 \\
2 \\
6\end{array}$ & 9 & $\begin{array}{l}4 \\
2 \\
6 \\
6\end{array}$ & $\begin{array}{l}3 \\
8 \\
9 \\
6\end{array}$ & $\begin{array}{l}8 \\
1 \\
5 \\
2\end{array}$ & $\begin{array}{l}4 \\
2 \\
9 \\
7\end{array}$ & $\begin{array}{l}4 \\
1 \\
3 \\
7\end{array}$ & $\begin{array}{l}1 \\
5\end{array}$ & $\begin{array}{l}4 \\
5\end{array}$ & $\begin{array}{l}5 \\
0 \\
9\end{array}$ & 3 & $\begin{array}{l}9 \\
1 \\
0 \\
5\end{array}$ & 4 & $\begin{array}{l}7 \\
1\end{array}$ & 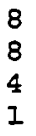 & $\begin{array}{l}5 \\
3 \\
4 \\
2\end{array}$ & 6 & & 2 & 5 & $\begin{array}{l}4 \\
1 \\
5 \\
5\end{array}$ & $\begin{array}{l}2 \\
6 \\
2 \\
6\end{array}$ & 2 & $\begin{array}{l}4 \\
4 \\
5 \\
9\end{array}$ & $\begin{array}{l}8 \\
5 \\
3 \\
8\end{array}$ & $\begin{array}{l}0 \\
4 \\
6\end{array}$ \\
\hline & 7 & 5 & & 1 & 1 & 3 & 2 & 3 & 6 & & 8 & & 8 & 5 & 4 & & 5 & 2 & & & & & & & & 1 & \\
\hline
\end{tabular}

To use the table, determine how many subjects are to be chosen, number the population 1 through $x$ (the number that are in the population) then start at any point in the table and go right, left, up, or down, until the required number are chosen.

EXAMPLES: If choosing a sample of one from a population of five, number the population one through five, go to the table and start at any point, and go in any direction until one of the numbers, one through five is reached. That will be the sample.

If choosing a sample of five from a population greater than nine, number the population one through $x x$, go to the table and start at any point (looking at numbers in pairs), and go in any direction until five of the numbers in the population are obtained. That will be the sample. 
APPENDIX D

POST CARD FOR HUMAN RESOURCES VICE-PRESIDENTS

118

Reproduced with permission of the copyright owner. Further reproduction prohibited without permission. 
POST CARD FOR HUMAN RESOURCES VICE-PRESIDENT

Dear Joe:

The Training Leader chosen to participate in your study is:

Name:

Title:

Company:

Phone:

Address:

City, state, ZIP:

My name is:

Company: 
APPENDIX $E$

LETTER FOR TRAINING LEADER

120

Reproduced with permission of the copyright owner. Further reproduction prohibited without permission. 
1244 Catawba Street

Kingsport, TN 37660-4506

(615) 247-1428 (home)

(615) 229-6691 (work)

May 20, 1995

Name

Title

Company

Street

City, State, Zip

Dear Mr/Ms :

Your Vice-President of Human Resources,

has selected you to participate in a survey I am doing a's

part of my dissertation. I am enrolled in a doctoral

program at East Tennessee State University. The study looks

at the relationship among the leadership style of training

leaders, the method of training, and organization

performance. I am trying to answer the questions: Does leadership style affect profitability? Does choice of training method affect profitability? I am requesting that you and five of your subordinates fill out a survey on leadership behavior and charisma and mail these to me.

This survey should provide some valuable information about leadership and training. I will send a condensation of my study for publication in a training journal, but cannot guarantee publication. The completed dissertation will be available for loan from East Tennessee State University and also from UMI Dissertation Services.

If you will participate, I will guarantee confidentiality. No organization will be identified in the study. To participate, choose five of your subordinates or direct reports. If you have more than five subordinates, use the attached random number table to choose five at random. Random selection is very important to insure the statistical validity of the study. Please fill the attached surveys and return to me in the envelope provided and give the other surveys to the chosen subordinates. In addition, please read, and sign the informed consent form and return one copy with the survey. The survey will take you approximately 15 minutes to complete and will take each of your subordinates approximately 10 minutes to complete. I will provide anonymous feedback to you on responses from your subordinates, if desired. This request is being sent to all Fortune 500 Companies that have been on the list for at least three years. 
Sincerely,

Joseph D. Keith 
APPENDIX F

DEMOGRAPHIC INFORMATION

123

Reproduced with permission of the copyright owner. Further reproduction prohibited without permission. 


\section{Demographic Information}

Please provide the following demographic information in the space provided. This information will be used in the study in a confidentia? manner.

1. Age, in Years

2. Gender:

Female Male

3. Racial/Ethnic Group:

$$
\text { African-American }
$$
, Asian-American Hispanic - Caucasian Other

4. Highest Educational Degree Earned:

High School , Bachelor's Master's Doctorate

5. Number of Employees in the Training Department

6. Number of Years in Your Current Employment Position 
APPENDIX G

TRAINING METHODS USED

125

Reproduced with permission of the copyright owner. Further reproduction prohibited without permission. 


\section{Training Methods Used}

Mark the following training methods that are used in your Company. Explanations of each method are included on the attached sheet.

\section{Method}

Use

1. Accelerated Learning

2. Audiotapes

3. Case Study Methods

4. Computer-based Training

5. Computer Conferencing

6. Experiential Exercises/Games Simulations

7. Films

8. Interactive Video

9. Lectures

10. Multimedia

11. Non-computerized Self-study

12. One-on-one Instruction

13. Problem-based Learning

14. Role Plays

15. Self-assessment/Self-testing Instruments

16. Slides

17. Teleconferencing (Audio only)

18. Video Teleconferencing

19. Videotapes 
Explanations of Methods

1. Accelerated Learning - is a combination of physical relaxation, mental concentration, guided imagery, suggestive principles, baroque music, comfortable surroundings, rhythmic mnemonics, games, stories, poetry, background posters, peripherals, and group interaction

2. Audiotapes - the use of audiocassette tapes for instructional or training purposes

3. Case Study Method - involves reporting an actual or make-believe situation, having the learners think about and analyze the case, and discussing the case with other people

4. Computer-based Training - consists of interactive tutorials and simulations containing text and possibly graphics that provide training by means of a main frame computer or a personal computer

5. Computer Conferencing - the use of the Internet or similar computer networks to conduct training sessions

6. Experiential Exercises/Games/Simulations - are games or situations where individuals or focus groups consisting of employees and supervisors interact to simulate real-world conditions.

7. Films - the use of 16 millimeter films as an instructional method

8. Interactive Video - is video that is presented on optical disks where the trainee can interact with the learning process.

9. Lectures - the use of traditional, stand-up oral presentations by an instructor as a training method

10. Multimedia - is a computer system combining text, graphics, video, animation, audio, hypertext, and data bases in one platform for instructional purposes.

11. Non-computerized Self-study - is any teaching situation where students take responsibility for their own learning and make decisions about the topic of study, objectives, resources, schedule, type and sequence of activities, environment, media, learning strategy, etc.

12. One-on-one Instruction - having one worker for instructor) train another worker, usually while on the job and doing actual work 
13. Problem-based Iearning - is a instructional strategy where the starting point is a problem that students may face in later life that is solved by students working in a group and assuming the responsibility for their own instruction and learning.

14. Role Plays - the use of assigning roles to class participants and having the participants play out the roles usually in pairs or larger groups to illustrate an instructional concept or to reinforce learning

15. Self-assessment/Self-testing Instruments - the use of instruments (tests or surveys) that are completed by the participant (or others) to learn the particular behaviors that the participant is exhibiting

16. Slides - the use of 35 millimeter slides as an instructional method

17. Teleconferencing (audio only) - is training delivered by voice only across hundreds of miles via telephone lines

18. Video Teleconferencing - is training (audio and visual) delivered across hundreds of miles via satellite or over short distances via local area networks.

19. Videotapes - training delivered by the use of VHS videotapes either in classroom settings or in self-study settings 
APPENDIX H

LPI-SELF

129

Reproduced with permission of the copyright owner. Further reproduction prohibited without permission. 


\section{LEADERSHIP PRACTICES INVENTORY (LPI) : SELF}

Name of Leader:

On the next two pages are thirty descriptive statements about various leadership behaviors and activities. Please read each statement carefully, then rate yourself in terms of how frequentiy you engage in the practice described. Record your responses by drawing a circle around the number that corresponds to the frequency you have selected. You are given five choices:

1. If you RARELY or NEVER do what is described in the statement, circle the number one.

2. If you do what is described ONCE IN A WHILE, circle the number two.

3. If you SOMETIMES do what is described, circle the number three.

4. If you do what is described FAIRIY OFTEN, circle the number four.

5. If you do what is described VERY FREQUENTIY or ALWAYS, circle the number five.

In selecting the answer, be realistic about the extent to which you actually engage in each behavior. Do not answer in terms of how you like to see yourself or in terms of what you should be doing. Answer in terms of how you typically behave. For example, the first statement is "I seek out challenging opportunities that test my skills and abilities." If you believe you do this "once in a while," circle the number two. If you believe you seek out challenging opportunities "fairly often," circle the number four. 


\section{LEADERSEIP RRACTICES INVENTORY (LPI) : SELF}

To what extent do you engage in the following actions and behaviors? Circle the number that applies to each statement.

\begin{tabular}{|c|c|c|c|c|}
\hline 1 & $\begin{array}{l}2 \\
\text { Once in } \\
\text { a While }\end{array}$ & Sometimes & $\begin{array}{l}\quad 4 \\
\text { Fairly } \\
\text { Often }\end{array}$ & $\begin{array}{c}5 \\
\text { Very } \\
\text { Frequently }\end{array}$ \\
\hline
\end{tabular}

1. I seek out challenging opportunities that test my skills and abilities.... . . . . . . . . . . . I 2345

2. I describe to others the kind of future I would like for us to create together............ 12345

3. I involve others in planning the actions that we will take..................... I 2345

4. I am clear about my own philosophy of

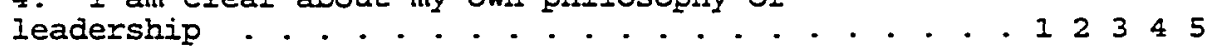

5. I take time to celebrate accomplishments when project milestones are reached... . . . . . . 12345 6. I stay up-to-date on the most recent developments affecting our organization. . . . . . . 12345 7. I appeal to others to share my dream of the future as their own.... . . . . . . . . . . . 12345 8. I treat others with dignity and respect. . . . . 12345 9. I make certain that the projects I manage are broken down into manageable chunks . . . . . . . . . I 2345 10. I make sure that people are recognized for their contributions to the success of our projects . . . . I2345 11. ' I challenge the way we do things at work . . . . 12345 12. I clearly communicate a positive and hopeful outlook for the future of our organization . . . . . 12345 13. I give people a lot of discretion to make their own decisions................. 12345 14. I spend time and energy on making certain that people adhere to the values that have been agreed on........................ 12345

15. I praise people for a job well done. . . . . . . I 2345 Copyright 1988 by James M. Kouzes and Barry $z$. Posner. All rights reserved. 


$\begin{array}{ccccc}1 & 2 & 3 & 4 & 5 \\ \text { Once in } & \text { Fairly } & \text { very } \\ \text { a While } & \text { Sometimes } & \text { Often } & \text { Frequently }\end{array}$

16. I look for innovative ways we can improve what

we do in this organization........... 12345

17. I show others how their Iong-term future

interests can be realized by enlisting in a common

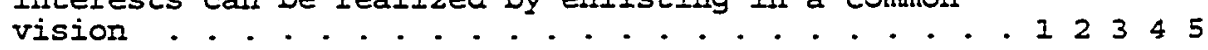

18. I develop cooperative relationships with the

people I work with ............. I 2345

19. I let others know my beliefs on how to best

run the organization I lead........... I 2345

20. I give the members of the team lots of

appreciation and support for their contributions. . 12345

21. I ask "what can we learn?" when things do not

go as expected . . . . . . . . . . . . . . . . . 12345

22. I look ahead and forecast what I expect

the future to be like............. I 2345

23. I create an atmosphere of mutual trust in the

projects I lead................ I I 2345

24. I am consistent in practicing the values

I espouse.................. 12345

25. I find ways to celebrate accomplishments... . 12345

26. I experiment and take risks with new approaches

to my work even when there is

a chance I might fail............... I 2345

27. I am contagiously excited and enthusiastic

about future possibilities .......... 12345

28. I get others to feel a sense of ownership for

the projects they work on............. 12345

29. I make sure the work group sets clear goals,

makes plans, and establishes milestones for the

projects I lead... . . . . . . . . . . . . . I 2345

30. I make it a point to tell the rest of the

organization about the good work done by

my group .................. 12345

Copyright $\odot 1988$ by James M. Kouzes and Barry z. Posner. All rights reserved. 
APPENDIX I

ACT-SELF

133

Reproduced with permission of the copyright owner. Further reproduction prohibited without permission. 


\section{The Affective Communication Test}

\section{Self-Description Questionnaire}

Please circle the appropriate number for each question as to whether the statement is true or false as it applies to you. A score of -4 would be given for completely false, with a score of +4 for completely true. Use other numbers for statements which are in between -4 and +4 .

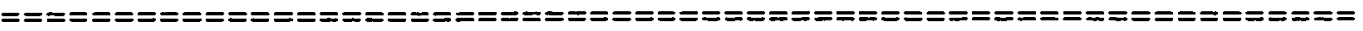

1. When I hear good dance

$\begin{array}{llllll}-4 & -3 & -2 & -1 & 0 & +1+2+3+4\end{array}$

music, I can hardly keep still.

2. My laugh is soft and subdued.

3. I can easily express emotion over the telephone.

4. I often touch friends during conversations.

5. I dislike being watched

by a large group of people.

6 . I usually have a neutral

facial expression.

7. People tell me that I

would make a good actor or actress.

8. I like to remain

unnoticed in a crowd.

9. I am shy among

strangers.

10. I am able to give a

seductive glance if I want

to

11. I am terrible at

$\begin{array}{lllllllll}-4 & -3 & -2 & -1 & 0 & +1+2+3+4\end{array}$

$\begin{array}{lllllllll}-4 & -3 & -2 & -1 & 0 & +1 & +2 & +3 & +4\end{array}$

$\begin{array}{lllllllll}-4 & -3 & -2 & -1 & 0 & +1 & +2 & +3 & +4\end{array}$

$\begin{array}{lllllllll}-4 & -3 & -2 & -1 & 0 & +1 & +2+3 & +4\end{array}$

$\begin{array}{lllllll}-4 & -3 & -2 & -1 & 0 & +1+2+3+4\end{array}$

$\begin{array}{lllllllll}-4 & -3 & -2 & -1 & 0 & +1 & +2 & +3 & +4\end{array}$

pantomime as in games

like charades.

12. At small parties I am

the center of attention.

13. I show that I like

someone by hugging or

touchirg that person.

$\begin{array}{lllllllll}-4 & -3 & -2 & -1 & 0 & +1 & +2+3+4\end{array}$

$\begin{array}{lllllllll}-4 & -3 & -2 & -1 & 0 & +1 & +2+3 & +4\end{array}$

$\begin{array}{llllll}-4 & -3 & -2 & -1 & 0 & +1+2+3+4\end{array}$

$\begin{array}{lllllllll}-4 & -3 & -2 & -1 & 0 & +1 & +2 & +3 & +4\end{array}$

$\begin{array}{lllllllll}-4 & -3 & -2 & -1 & 0 & +1 & +2 & +3 & +4\end{array}$

$\begin{array}{llllll}-4 & -3 & -2 & -1 & 0 & +1+2+3+4\end{array}$ 
APPENDIX J

INFORMED CONSENT FORM 


\begin{abstract}
FORM 106
East Tannessee State University INFORMED CONSENT FORM
\end{abstract}

PRINCIPAI INVESTIGATOR: JOseph D. Keith

TITLE OF PROJECT: "The Relationship among Leadership Behaviors of Leaders in Training Organizations, Training Methods, and Organization Profitability"

PURPOSE The purposes of the study are:

1). to determine if there is a relationship between leadership behaviors of leaders in training organizations and organization profitability

2). to determine if there is a relationship between leadership behaviors of leaders in training organizations and training methods used; and

3). to determine if there is a relationship between training methods used and organization profitability.

DURATION The expected duration of the participant's time will be between 10 to 15 minutes.

PROCEDURES The surveys will be mailed to the participants and then mailed back to the principal investigator.

POSSIBLE RISZS/DISCOMFORTS There are no discomforts, inconveniences, and/or risks that are reasonably expected.

CONTACT FOR OUESTIONS If you have any further questions about this study you may call Joseph D. Keith at (615) 247-1428 or Dr Donn Gresso at (615) 929-4251.

Further information about research subject's rights and whom to contact in the event of a research-related injury may be obtained from the Chairman of the Insticutional Review Board at (615) 929-6134.

Although your rights and privacy will be maintained, the secretary of the Department of Health and Human Services and the ETSU Institutional Review Board do have free access to any information obtained in this study should it become necessary and should you freely and voluntarily choose to participate. You may withdraw at any time without prejudice.

DRUGS AND DEVICES UNDER FDA REGUTATION: YOu understand that because this study does not involve articles regulated by the FDA (Food and Drug Administration), the FDA may not choose to inspect records which identify you as a subject in this investigation.

Your study record will be maintained in strictest confidence according to current legal requirements and will not be revealed unless required by law or as noted above.

COMPENSATION FOR MEDICAI TREATMENT: East Tennessee state University does not provide compensation for medical treatment other than emergency first aid, for any injury which may occur as a result of your participation as a subject in this study, claims arising against ETsJ or any of its agents or employees may be submitted to the Tennessee Claims Commission for disposition to the extent allowable as provided under TCA 
Section 9-8-307. Further information concerning this may be obtained from the Chairman of the Institutional Review soard at (615) 929-6134.

WITNESSING AND SIGNATURES: The nature, demands, risks, and benefits of the project have been explained to me as well as is known and available. I understand what my participation involves. Furthermore, I understand that I am free to ask questions and withdraw from the project at any time, without peralty. I have read and fully understand the consent form. I sign it freely and voluntarily. A signed copy has been given to me.

Signature of Volunteer

$\overline{\text { Date }} \overline{\text { Signature of Investigator }}$

$\overline{\text { Date }}$ 
APPENDIX $K$

LETTER FOR TRAINING STJBORDINATE 
1244 Catawba Street

Kingsport, TN 37660-4506

(615) 247-1428 (home)

(615) 229-6691 (work)

May 20, 1995

Dear Fellow Trainer:

Your training leader has chosen you to participate in a survey I am doing as part of my dissertation. I am enrolled in a doctoral program at East Tennessee State University.

The study looks at the relationship among the leadership style of training leaders, the method of training, and organization performance. I am trying to answer the questions: Does leadership affect profitability? Does choice of training method affect profitability? I am requesting that you fill out a survey on leadership and charisma concerning your leader and return to me by mail. I will provide anonymous feedback to your leader, if desirea.

This survey should provide some valuable information about leadership and training. I will send a condensation of my study for publication in a training journal, but cannot guarantee publication. The completed dissertation will be available for loan from East Tennessee State University and also from UMI Dissertation Services.

If you will participate, I will guarantee confidentiality. No organization will be identified in the study. To participate, please fill the attached survey and return to me in the envelope provided. In addition, please read, and sign the informed consent form and return one copy with the survey. The survey will take the you approximately 10 minutes to complete. This request is being sent to all Fortune 500 Companies that have been on the list for at least three years.

Sincerely,

Joseph D. Keith 
APPENDIX I

LPI-OTHER

140

Reproduced with permission of the copyright owner. Further reproduction prohibited without permission. 
LEADERSEIP FRACTICES INVENTORY

\section{P I Other}

Name of Leader:

The Leadership Practices Inventory (LPI): Other is designed to assist a leader in identifying the extent to which he or she engages in certain leadership practices. You are being asked by one of your colleagues to assess him or her on thirty leadership practices.

\section{Instructions}

The name of the person you will assess appears in the space marked "Name of Leader."

On the next two pages are thirty descriptive statements about various leadership behaviors and activities. Please read each statement carefully, then rate the leader whose name appears on this page in terms of how frequently he or she engages in the practice described. Record your responses by drawing a circle around the number that corresponds to the frequency you have selected. You are given five choices:

1. If the leader RARELY or NEVER does what is described in the statement, circle the number one.

2. If the leader does what is described ONCE IN $A$ WhILE, circle the number two.

3. If he or she SOMETIMES does what is described, circle the number three.

4. If he or she does what is described FAIRLY OFTEN, circle the number four.

5. If the leader does what is described VERY

FREQUENTLY or ALWAYS, circle the number five.

In selecting the answer, be realistic; answer in terms of how the person typically behaves. For example, the first statement is "He or she seeks out challenging opportunities that test his or her skills and abilities." If you believe he or she does this "once in a while," circle the number two. If you believe he or she seeks out challenging opportunities "fairly often," circle the number four. 


\section{IEADERSHIP PRACTICES INVEINTORY (LPI): OTEER}

To what extent would you say tinis person engages in the following actions and behaviors? Circle the number that appiies to each statement.

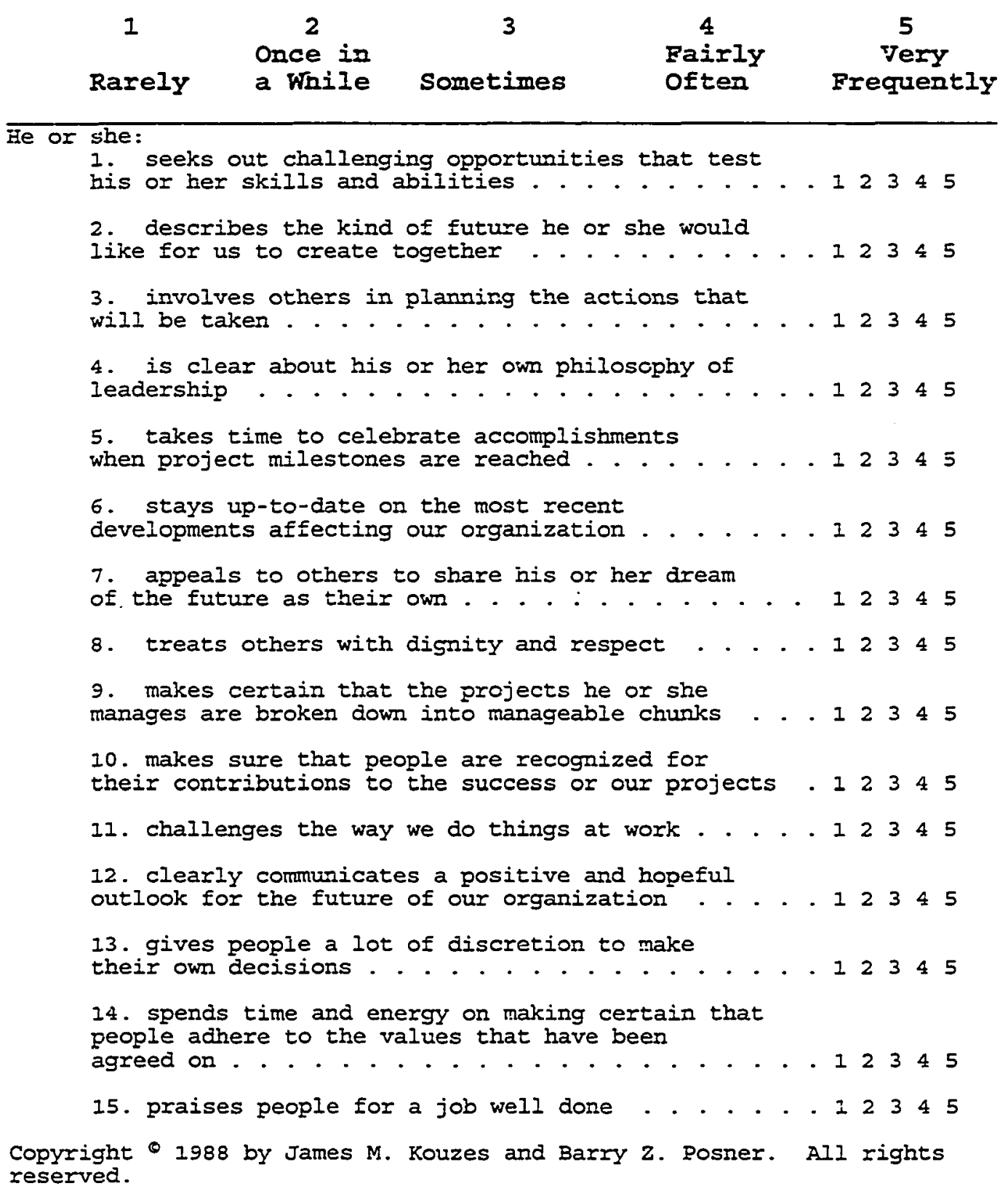







APPENDIX M

ACT-OTHER

144

Reproduced with permission of the copyright owner. Further reproduction prohibited without permission. 


\section{The Afiective Communication Test Other-Description Questionnaire}

Please circle the appropriate number for each question as to whether the statement is true or false as it applies to your leader. A score of -4 would be given for completely faise, with a score of +4 for completely true. Use other numbers for statements which are in between -4 and +4 .

1. When he or she hears good dance music, he or she can haraly keep still.

2. His or her laugh is soft and subdued.

3. He or she can easily express emotion over the telephone.

4. He or she often touches friends during conversations.

5. He or she dislikes being watched by a large group of people.

6 . He or she usually has a neutral facial expression.

7. People tell him or her that he or she would make a good actor or actress. 8. He or she likes to remain unnoticed in a crowd.

9. He or she is shy among strangers.

10. He or she is able to give a seductive glance if he or she wants to

11. He or she is terrible at pantomime as in games like charades.

12. At small parties he or she is the center of attention.

13. He or she shows that he or she likes someone by hugging or touching that person.

$$
\begin{array}{lllllllll}
-4 & -3 & -2 & -1 & 0 & +1 & +2 & +3 & +4 \\
-4 & -3 & -2 & -1 & 0 & +1 & +2 & +3 & +4 \\
-4 & -3 & -2 & -1 & 0 & +1 & +2 & +3 & +4 \\
-4 & -3 & -2 & -1 & 0 & +1 & +2 & +3 & +4 \\
-4 & -3 & -2 & -1 & 0 & +1 & +2 & +3 & +4 \\
-4 & -3 & -2 & -1 & 0 & +1 & +2 & +3 & +4 \\
-4 & -3 & -2 & -1 & 0 & +1 & +2 & +3 & +4 \\
-4 & -3 & -2 & -1 & 0 & +1+2 & +3+4 \\
-4 & -3 & -2 & -1 & 0 & +1 & +2 & +3 & +4 \\
-4 & -3 & -2 & -1 & 0 & +1 & +2 & +3 & +4 \\
-4 & -3 & -2 & -1 & 0 & +1+2+3+4 \\
-4 & -3 & -2 & -1 & 0 & +1+2 & +3+4
\end{array}
$$


APPENDIX N

LETTER FROM DR. BARRY POSNER

146

Reproduced with permission of the copyright owner. Further reproduction prohibited without permission. 


\section{KOUZES POSNER INTERNATIONAL, INC. 15419 Banyan Lane \\ Monte Sereno, California 95030 Phone/FAX: 408-354-9170}

January 20, 1995

Mr. Joseph D. Keith

1244 Catawba Street

Kingsport, Tennessee 37660-4506

Dear Josepin:

Thank you for your letter (dated 13 January) requesting permission to use the Leadership Practices Inventory (LPI) in your dissertation. We are pleased to allow you to reproduce the LPI in your research project to the extent outlined in your letter and according to the following three stipulations:

1. That the following copyright notice appear on all copies of the LPI-Self and LPI-Observer: Copyright ${ }^{\circ} 1993$ Kouzes Posner International, Inc. Used with permission.

2. That we receive copies of all reports, papers, presentations, etc., including a bound copy of your dissertation, which utilize any of the LPI data from this study.

3. That the LPI may not be re-sold or re-packaged in any other programs or workshop settings without express written permission.

If you agree to the terms outlined above, please sign one copy cf this letter and return it to the address above. Enclosed is an article providing more technical information about the instrument's psychometric properties.

If we can be of any further assistance, please do not hesitate to let us know. Best wishes in your research efforts.

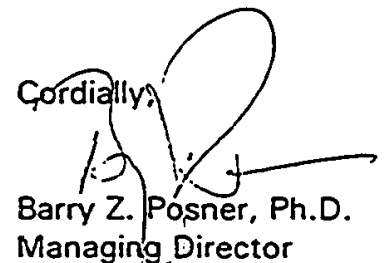

I uncierstand and agree to abide by these terms:

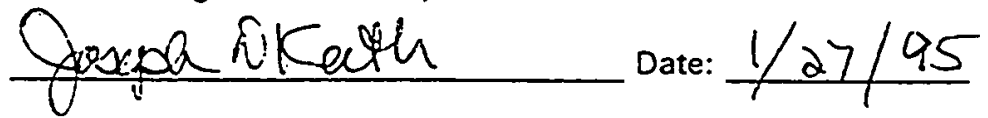


APPENDIX 0

LETTER FROM INSTITUTIONAL REVIEW BOARD

148

Reproduced with permission of the copyright owner. Further reproduction prohibited without permission. 


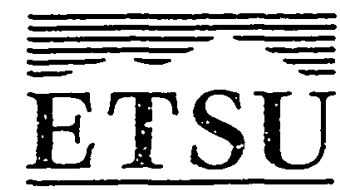

East Tennessee State University

institutional Review Board - Box 70565 - Johnson City. Tennessee 37614-0565 - (615) 929-6134

TO: Joseph D. Keith

FROM: David N. Walters, M.D., Chairman

Institutional Review Board

DATE: June 19, 1995

SUBJECT: The Relationship Among Leadership Benaviors of Leaders in Training Organizations, Training Methods, and Organization Profitability.

IRB \#95-001e

I have reviewed the above-referenced study and find that it qualifies for exemption from further IRB review. Federal Guidelines Title 45-Part 46.101 allows for categories of studies to be exempted from furnher IRB review.

If you feel it is necessary to call further $\mathbb{R B}$ attention to any aspects of this project, please refer to the abcve-titled project and IRB\# 95-001e.

I appreciate your bringing this project bcfore the IRKB for its concurrence of exempt status. Good luck with your study.

Respectfully submitted,

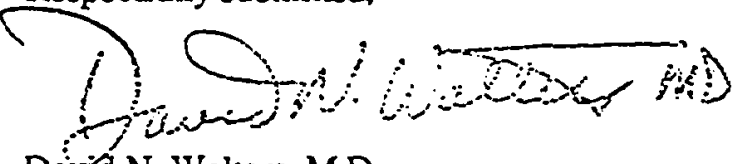

Daviá N. Walters, M.D.

Chairman, IRB 
VITA

JOSEPH DAVID KEITH

\begin{tabular}{|c|c|}
\hline Personal Data: & $\begin{array}{l}\text { February } 26,1942 \\
\text { Rome, Georgia } \\
\text { Married }\end{array}$ \\
\hline Education: & $\begin{array}{l}\text { Public Schools, Rome, Georgia } \\
\text { Georgia Institute of Technology, } \\
\text { Atlanta, Georgia, B.S., I964 } \\
\text { Institute of Textile Technology, } \\
\text { Charlottesville, Virginia, M.S., } \\
1966 \\
\text { East Tennessee State University, } \\
\text { Johnson City, Tennessee, MBA, } 1977 \\
\text { East Tennessee State University, } \\
\text { Johnson City, Tennessee, } \\
\text { Educational Leadership and Policy } \\
\text { Analysis, Ed.D., 1995 }\end{array}$ \\
\hline $\begin{array}{l}\text { Professional } \\
\text { Experience }\end{array}$ & $\begin{array}{l}\text { Senior Textile Technologist, Principal } \\
\text { Training Representative, Eastman } \\
\text { Chemical Company, 1966-Present } \\
\text { Captain, Quartermaster Corps, U.S. Army, } \\
\text { 1967-1969 }\end{array}$ \\
\hline $\begin{array}{l}\text { Professional } \\
\text { Membership }\end{array}$ & $\begin{array}{l}\text { Americar Association for Textile } \\
\text { Technology } \\
\text { American Society for Training and } \\
\text { Development } \\
\text { National Society for Performance } \\
\text { and Instruction } \\
\text { Delta Kappa Phi } \\
\text { Phi Kappa Phi } \\
\text { Phi Delta Kappa }\end{array}$ \\
\hline Publications & $\begin{array}{l}\text { Keitin, J. D. (Sept 1977). Polyester } \\
\text { processing problems and answers. } \\
\text { Textile Industries. } \\
\text { Keith, J. D. (Oct 1992). Lecture or } \\
\text { learner controlled training. } \\
\text { Performance and Instruction. } \\
\text { Keith, J. D. and Payton, E. (Feb 1995). } \\
\text { Empowered employees in the learning } \\
\text { organization. Training and } \\
\text { Development. }\end{array}$ \\
\hline
\end{tabular}

